\title{
Constitutive Transcription of Yeast Ribosomal Protein Gene TCMI Is Promoted by Uncommon cis- and trans-Acting Elements
}

\author{
KATHERINE G. HAMIL,${ }^{1}$ HONG GIL NAM ${ }^{2}$ AND HOWARD M. FRIED ${ }^{1 *}$ \\ Department of Biochemistry, University of North Carolina, Chapel Hill, North Carolina 27599, ${ }^{1}$ and Department of \\ Molecular Biology, Massachusetts General Hospital, Boston, Massachusetts $02114^{2}$
}

Received 8 June 1988/Accepted 28 July 1988

\begin{abstract}
The DNA sequence UAS $_{\mathrm{T}}$ (TCGTTTTGTACGTTTTTCA) was found to mediate transcription of yeast ribosomal protein gene $T C M 1$. UAS $\mathrm{T}_{\mathrm{T}}$ was defined as a transcriptional activator on the basis of loss of transcription accompanying deletions of all or part of $\mathrm{UAS}_{\mathrm{T}}$, orientation-independent restoration of transcription promoted by a synthetic $\mathrm{UAS}_{\mathrm{T}}$ oligomer inserted either into $T C M 1$ or into the yeast $C Y C 1$ gene lacking its transcriptional activation region, and diminished transcription following nucleotide alterations in $U_{A} S_{T}$. UAS bound in vitro to a protein denoted TAF (TCM1 activation factor); TAF was concluded to be a transcriptional activator protein because nucleotide alterations in $\mathrm{UAS}_{\mathrm{T}}$ that diminished transcription in vivo also diminished TAF binding in vitro. The sequence of $\mathrm{UAS}_{\mathrm{T}}$ bore no obvious resemblance to $\mathrm{UAS}_{\mathrm{rpg}}$, the principal cis-acting element common to most yeast ribosomal protein genes. Likewise, TAF was distinguished from the UAS $_{\text {rpg }}$-binding protein TUF, since (i) TAF and TUF were chromatographically separable, (ii) binding of either TAF or TUF to its corresponding UAS was unaffected by an excess of UAS rpg $_{\text {or }}$ UAS $_{T}$ DNA, respectively, and (iii) photochemical cross-linking experiments showed that TAF was a protein of 147 kilodaltons (kDa), while TUF was detected as an approximately 120 -kDa polypeptide, consistent with its known size. Cross-linking experiments also revealed that both $U A S_{T}$ and $U A S_{r p g}$ bound a second heretofore unobserved 82-kDa protein; binding of this additional protein appeared to require binding of TAF or TUF. On the basis of the biochemical characterization of TAF and a lack of sequence similarity between $U_{A S}$ and $U A S_{r p g}$, we suggest that transcription of TCM1 is mediated by a cis-acting sequence and at least one trans-acting factor different from the elements which promote transcription of most other ribosomal protein genes. A second trans-acting factor may be shared by $T C M I$ and other ribosomal protein genes; this factor could mediate coordinate regulation of these genes.
\end{abstract}

In all cells, synthesis of ribosomal proteins (rp) is constrained by two economic conditions. First, because each protein is present in a unit amount in the ribosome, each is produced at the same rate $(11,47)$. For Saccharomyces cerevisiae, equivalent synthesis rates of rp are due largely to the existence of an equal quantity of mRNA for each polypeptide $(19,49)$. Secondly, rp synthesis is generally limited to producing just the number of ribosomes required by a given growth milieu $(21,32,48)$. Again for $S$. cerevisiae, a particular level of rp synthesis is achieved by coordinate adjustments in the abundance of all rp mRNAs, probably by changes in rp gene transcription $(7,13,18)$. This balanced and coordinated expression of yeast rp genes is striking considering the large number of transcription units involved (probably more than 100) and the fact that some rp mRNAs are products of single-copy genes $(8,33)$ while other rp mRNAs are derived by transcription of a pair of duplicate genes $(2,30,35,49)$.

These two conditions, equimolar amounts of rp mRNAs and coordinate adjustments in rp gene transcription, are attributable to a set of cis- and trans-acting elements common to yeast rp genes (for a review, see reference 25). Most yeast rp genes possess one or two versions of the consensus DNA upstream activation sequence $\mathrm{UAS}_{\mathrm{rpg}}$, present in either orientation 200 to 400 base pairs (bp) $5^{\prime}$ of rp coding sequences. $U_{A S}$ binds in vitro to a protein called TUF, the likely candidate for a transcription activation factor. Deletion of $\mathrm{UAS}_{\mathrm{rpg}}$ elements renders rp genes transcription-

\footnotetext{
* Corresponding author.
}

ally inactive, presumably due to an absence of TUF factor interaction $(23,36,40,51)$. Conversely, insertion of $U_{A S}$ sequences reactivates transcription $(36,50)$. Each $\mathrm{UAS}_{\mathrm{rpg}}$ sequence possesses a different ability to stimulate transcription, which correlates with its relative affinity for the TUF factor (46). Such differences in activation efficiency among UAS $_{\text {rpg }}$ sequences explain how single-copy rp genes yield mRNA levels equivalent to those of duplicated genes, i.e., the UAS ${ }_{\mathrm{rpg}}$ sequences of duplicated genes bind TUF factor less efficiently than do single-copy genes. Thus, rp gene promoters are amalgams of TUF factor binding sites varying in number, orientation, and affinity for TUF factor, which together promote comparable synthesis of each rp mRNA.

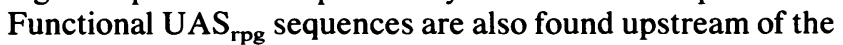
$T E F 1$ and TEF2 genes, which encode elongation factor EF-1 $\alpha$ (14); other suspected TUF binding sites have been noticed adjacent to a gene encoding a common subunit of RNA polymerase I and III (26) and the gene encoding initiation factor eIF-4E (3). Consequently, UAS ${ }_{\mathrm{rpg}} / \mathrm{TUF}$ is seen as a general factor that promotes transcription of genes encoding the yeast transcriptional and translational machinery.

As far as regulation is concerned, one $\mathrm{UAS}_{\mathrm{rpg}}$ sequence has been shown to be capable of mediating an environmentally induced change in transcription (13). After cells were shifted from a poor carbon source (ethanol) to glucose, a three- to fivefold increase in transcription was observed for both rp gene L25 and a heterologous gene into which an L25-UAS $_{\text {rpg }}$ was inserted. Since synthesis of all rp is stimulated by carbon source upshift $(7,17)$ and most rp genes 
possess at least one $\mathrm{UAS}_{\mathrm{rpg}}$ sequence, it has been suggested that $\mathrm{UAS}_{\mathrm{rpg}} / \mathrm{TUF}$ mediates coordinate regulation of all rp genes $(14,25)$.

The occurrence of a common cis-acting element in yeast rp gene transcription was originally determined by comparisons of DNA sequences adjacent to those genes $(24,43)$. Of 21 genes examined, 19 shared homology to what is now defined as the $\mathrm{UAS}_{\mathrm{rpg}}$ consensus sequence. The two genes that appeared to lack UAS ${ }_{\text {rpg }}$ were $T C M I$ and $S 33$, although $T C M I$ and $S 33$ were seen to contain, along with potential TATA homologies, nearby T-rich stretches characteristic of most yeast genes $(25,36,46)$. In view of the widespread occurrence of TUF factor binding sites in genes of the yeast translational and transcriptional machinery, coupled with suggestions that a common mechanism coordinates expression of these genes, it is imperative to identify the respective sequence elements that promote transcription of TCMI and $S 33$ and to determine whether those elements are TUF dependent.

In this report, we describe a DNA sequence and its corresponding binding protein which are responsible for $>90 \%$ of the transcriptional activation of $T C M 1$. The cisacting sequence, designated $\mathrm{UAS}_{\mathrm{T}}$ (upstream activation sequence of $T C M I$ ), normally spans residues 193 to 211 upstream of the major TCMI transcription start site. $\mathrm{UAS}_{\mathrm{T}}$ activated transcription of $T C M 1$, as well as of a heterologous gene, in an orientation-independent manner. Nucleotide substitutions in $\mathrm{UAS}_{\mathrm{T}}$ reduced gene expression, confirming the transcriptional function of $\mathrm{UAS}_{\mathrm{T}}$. In confirmation of earlier rp gene comparisons, the sequence of $U A S_{T}$ showed no resemblance to the $\mathrm{UAS}_{\mathrm{rpg}}$ element common to most other rp genes.

DNA footprinting and mobility shift assays were used to identify a $\mathrm{UAS}_{\mathrm{T}}$-binding protein. The protein identified in vitro, designated TAF (TCMI activation factor), likely promotes transcription of $T C M I$, since the nucleotide alterations in $\mathrm{UAS}_{\mathrm{T}}$ that reduced TCMI transcription also led to diminished binding of TAF in vitro. Lack of homology between $\mathrm{UAS}_{\mathrm{T}}$ and $\mathrm{UAS}_{\mathrm{rpg}}$ was paralleled by biochemical differences between TAF and TUF (the UAS ${ }_{\mathrm{rpg}}$ binding protein). The two proteins were separated by column chromatography. Further, TAF did not bind to a UAS rpg $_{\text {se- }}$ quence when that sequence was present in a 1,500-fold molar excess over UAS $_{\mathrm{T}}$, nor did TUF factor bind to the same excess of $\mathrm{UAS}_{\mathrm{T}}$. Finally, photochemical cross-linking of TAF to radiolabeled UAS $_{T}$ DNA, followed by sodium dodecyl sulfate (SDS)-gel electrophoresis, showed that TAF had an apparent molecular mass of about 147 kilodaltons (kDa), while TUF was observed as an approximately 120$\mathrm{kDa}$ protein, consistent with its known size (41). Unexpectedly, cross-linking experiments also revealed that both $\mathrm{UAS}_{\mathrm{T}}$ and $\mathrm{UAS}_{\mathrm{rpg}}$ bound a previously unidentified $82-\mathrm{kDa}$ protein, whose binding appeared to require prior binding of TAF or TUF. We propose that constitutive transcription of at least one yeast rp gene is mediated by a set of cis- and trans-acting elements different from the elements common to most other rp genes. An additional protein, which is shared by the promoters for TCMI and other rp genes, could mediate coordinate regulation of these genes.

\section{MATERIALS AND METHODS}

Bacterial and yeast strains. Plasmids were propagated in Escherichia coli MC1061 [araD139 $\Delta$ (ara-leu)7697 AlacX74 galU galK hsr rpsL] provided by M. Casadaban or BM150 (dam hsr Tnl0) from M. Johnston. Promoter- $\beta$-galactosi- dase fusions were expressed in Saccharomyces cerevisiae DBY745 (mat $\alpha$ ura3-52 ade1-101 leu2-3,112) from D. Botstein. TCMI-CYCI fusions were expressed in $S$. cerevisiae E480-1D (mata cycl-363 cyc7-28 leu2-3,112 ura3-52) obtained from B. Errede. S. cerevisiae 20B-12 (mat $\alpha$ pep4-3 trpl) was obtained from the Yeast Genetics Stock Center and used for preparation of extracts containing DNA-binding proteins.

TCMI promoter- $\beta$-galactosidase fusions. We described previously (8) a series of plasmids in which at various positions upstream of TCMI a transcriptional regulatory sequence, derived from the GALIO gene, was placed and to which the $E$. coli $\beta$-galactosidase (lacZ) coding sequence was joined 43 nucleotides downstream of the $T C M I$ start site. To examine expression of these genes without the GAL10 element but dependent only upon TCMI 5' sequences, each plasmid was cleaved at a XhoI site between GALIO and TCMI and at an Sst $\mathrm{I}$ site in lacZ. The TCMI-lacZ segments were inserted into pLG669-ZX, a modified version of pLG669-Z (12) that contained a XhoI site at the end of the URA3 gene. The resulting plasmids, designated pTCM-Z1 through pTCM-Z7, contained various extents of TCMI 5'-flanking sequence (abutting the end of URA3) followed downstream by 43 nucleotides of $T C M I$-transcribed sequence, at which point $T C M I$ joined lac $Z$ (see Fig. 1 for a pictorial representation of these plasmids). Two other plasmids were also constructed. pTCM-Z8 was identical to pTCM-Z3 except that the sequence between -145 and -97 of TCMI was deleted; likewise, pTCM-Z9 was the same as pTCM-Z3 except that the sequence between -202 and -145 was deleted.

To provide convenient probes for proteins that bound specifically to the promoter, the TCMI segments were excised from plasmids pTCM-Z1 through pTCM1-Z7 by cleaving at the $X h o I$ site upstream of each segment and at the BamHI site that marked the junction between TCMI and lac $Z$ in each plasmid. The fragments were inserted into pUC19, yielding a source of promoter segments progressively truncated at their $5^{\prime}$ ends and terminating 43 bp $3^{\prime}$ of the transcription start point. This series of plasmids was named pUC-Z1 through -Z7. In addition, a 91-bp promoter segment of $T C M 1$ spanning a $B C l$ restriction site at -146 and an $\mathrm{HpaI}$ site at -236 was subcloned into pUC19, yielding pUC-Z8.

To compare protein binding to the TCMI promoter with

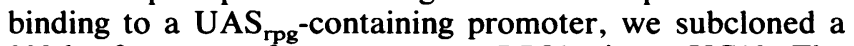
392-bp fragment of yeast rp gene RP5IA into pUC19. The fragment, extending from an $A s u I I$ site at -416 to a $B g$ III site at -24 , was derived from plasmid YIpRP51A (44), obtained from M. Rosbash.

TCM1-CYC1 hybrid genes. Plasmid pLG669-Z contained a 1,100-nucleotide fragment of the yeast $C Y C l$ gene, extending from $\sim 1,100 \mathrm{bp} 5^{\prime}$ of its transcription start site to $\sim 15 \mathrm{bp}$ into the $C Y C l$ coding sequence; at $+15, C Y C l$ was joined to the $\beta$-galactosidase coding sequence. To test the ability of $T C M I$ upstream sequence to activate transcription of the $C Y C 1$-lacZ gene, we replaced a segment of $C Y C I$ encompassing all of the DNA necessary to activate transcription (located between an $\mathrm{XhoI}$ site at -700 and a $B c$ II site at -80 ) with a XhoI-BclI fragment of TCMI, excised from plasmid pTCM-Z3 (see above), extending from -236 to -145 of TCMI. The plasmid was designated pTCYC-Z. A control plasmid, pCYC $\Delta \mathrm{X}-\mathrm{Z}$, lacking all $C Y C l$ activation sequences, was produced by digesting pLG669-Z with XhoI and rejoining, thereby deleting the region between -180 and -700 .

Derivatives of pLG669-Z, pTCYC-Z, and pCYCDX-Z 
which transcribed the entire $C Y C I$ coding sequence rather than a $C Y C I$-lacZ fusion were produced by replacing the $C Y C 1$ segment between $-80(B C l I)$ and $+15(B a m H I)$ in each plasmid with a 1,500-bp BclI-BamHI fragment of $C Y C I$ extending from the same -80 position to beyond the coding portion of $C Y C l$. The 1,500-bp $C Y C l$ segment was obtained from plasmid pAB16, kindly provided by $F$. Sherman.

Insertion of $\mathrm{UAS}_{\mathrm{T}}$ into promoters lacking an activation sequence. A 19-residue DNA oligonucleotide TCGTTTTGT ACGTTTTTCA and its complement were synthesized and annealed. This sequence is denoted $\mathrm{UAS}_{\mathrm{T}}$ and corresponds to positions -193 to -211 upstream of the TCMI transcription start site. $\mathrm{UAS}_{\mathrm{T}}$ was inserted into the following plasmids at their XhoI sites (filled in with DNA polymerase) that marked the upstream endpoint of each TCMI or CYCI promoter deletion (see above and Fig. 7 and 2, respectively): pTCM-Z5 (XhoI site at -186 of TCMI), pTCM-Z6 (XhoI site at -145 of $T C M I)$, pCYC $\triangle \mathrm{X}-\mathrm{Z}$ (Xhol site at -180 of $C Y C I)$, and pCYC $5^{\prime}-\mathrm{Z}$ (XhoI site at -180 of $C Y C l$ ). pCYC $\Delta \mathrm{X}-\mathrm{Z}$ and $\mathrm{pCYC} \Delta 5^{\prime}-\mathrm{Z}$ were analogous; as described above, the $-180 X$ XhoI site in pCYC $\triangle \mathrm{X}-\mathrm{Z}$ was preceded by DNA derived from -700 to -1100 of $C Y C l$ whereas in pCYC $\triangle 5^{\prime}$ $\mathrm{Z}$ all $C Y C I$ sequences beyond -180 were absent and the -180 site abutted the $3^{\prime}$ end of the URA3 gene. Since insertion of $\mathrm{UAS}_{\mathrm{T}}$ at the filled-in $X$ hol sites created a $P v u I$ site at one end of the oligomer, the orientation of the inserted $\mathrm{UAS}_{\mathrm{T}}$ segment was determined by digestion with $P v u I$ and a second enzyme having a cleavage site in adjacent $T C M I$ or $C Y C l$ sequences. These constructs, as well as those with altered $\mathrm{UAS}_{\mathrm{T}}$ sequences, were also verified by direct sequencing of the relevant regions of the plasmids (38).

Determination of plasmid copy number. All of the plasmids used in this study carried the yeast $U R A 3$ gene which encodes orotidine-5'-monophosphate decarboxylase (ODCase). Since the level of ODCase is directly proportional to gene dosage (10), plasmid copy numbers were quantitated from the specific activity of ODCase in cell extracts, relative to the ODCase activity of a wild-type strain with a single $U R A 3$ gene. ODCase activity was measured by release of ${ }^{14} \mathrm{CO}_{2}$ from orotidine-5'-monophosphate by the method of Prabhakararao and Jones (34). This method was more rapid than Southern blotting and free of the ambiguities inherent in densitometry of autoradiographs. Plasmid copy number was also assessed from RNA blot hybridization to quantitate the URA3 mRNA (data not shown). Results of both analyses were in agreement. The actual plasmid copy numbers are given in the legends to Fig. 1, 2, and 7.

$\boldsymbol{\beta}$-Galactosidase enzyme assay. Yeast cells $(10 \mathrm{ml})$, grown to about $10^{7}$ cells per $\mathrm{ml}$, were harvested, washed once in water, and then suspended in $Z$ buffer (29). Cells were disrupted by vigorous shaking with glass beads. Duplicate aliquots of the unclarified extracts were assayed for $\beta$ galactosidase activity by hydrolysis of $o$-nitrophenyl- $\beta-\mathrm{D}$ galactosidase (29). All measurements were performed on at least two different extracts of each strain.

Preparation of fractionated yeast extracts. One liter of yeast cells grown in $2 \%$ glucose-2\% peptone-1\% yeast extract was collected at mid-log phase. The resulting 2 to $3 \mathrm{~g}$ of cells was washed once with ice-cold water, suspended in $10 \mathrm{ml}$ of buffer $\mathrm{C}$ (as in reference 37 except that $10 \mu \mathrm{g}$ of leupeptin per $\mathrm{ml}$ was substituted for $1 \mathrm{mM}$ phenylmethylsulfonyl fluoride) and disrupted by vortexing with an equal volume of glass beads. After unbroken cells were pelleted by centrifugation $(4,000 \times g$ for $5 \mathrm{~min})$, the supernatant was removed and the glass beads were washed with buffer $\mathrm{C}$ to give a pooled supernatant of $8 \mathrm{ml}$. The supernatant was centrifuged at $145,000 \times g$ for $30 \mathrm{~min}$ at $4^{\circ} \mathrm{C}$. This cleared supernatant was removed, diluted to $0.1 \mathrm{M}\left(\mathrm{NH}_{4}\right)_{2} \mathrm{SO}_{4}$ with column buffer (37), and applied to a column of heparin agarose $(25 \mathrm{ml}, 1.0 \times 50 \mathrm{~cm})$ equilibrated with column buffer containing $0.1 \mathrm{M}\left(\mathrm{NH}_{4}\right)_{2} \mathrm{SO}_{4}$. The column was eluted at 1.3 $\mathrm{ml} / \mathrm{min}$ with $75 \mathrm{ml}$ of buffer at $0.1 \mathrm{M}\left(\mathrm{NH}_{4}\right)_{2} \mathrm{SO}_{4}$ followed by $50 \mathrm{ml}$ each of buffers containing $0.25,0.5$, and $0.75 \mathrm{M}$ $\left(\mathrm{NH}_{4}\right)_{2} \mathrm{SO}_{4}$. Fractions from each salt wash were pooled, dialyzed, aliquoted, and frozen at $-70^{\circ} \mathrm{C}$. Once binding activity was located in a particular $\left(\mathrm{NH}_{4}\right)_{2} \mathrm{SO}_{4}$ step fraction, succeeding columns were eluted with $75 \mathrm{ml}$ of buffer at $0.1 \mathrm{M}$ $\left(\mathrm{NH}_{4}\right)_{2} \mathrm{SO}_{4}$ followed with $100 \mathrm{ml}$ of a linear gradient from 0.1 $\mathrm{M}$ to $0.4 \mathrm{M}\left(\mathrm{NH}_{4}\right)_{2} \mathrm{SO}_{4}$. Fractions were collected, brought to $12 \%$ glycerol, aliquoted, and stored at $-70^{\circ} \mathrm{C}$. The gradient was monitored by $A_{280} ;\left(\mathrm{NH}_{4}\right)_{2} \mathrm{SO}_{4}$ concentrations were determined from conductivity measurements, and protein concentration were measured by the method of Bradford (4).

In initial experiments to identify DNA-binding activities and in binding competition experiments, we did not adjust the concentration of ammonium sulfate in various column fractions, since the levels of ammonium sulfate did not interfere with binding (data not shown). For DNA footprinting experiments (see below), samples were dialyzed to remove $\left(\mathrm{NH}_{4}\right)_{2} \mathrm{SO}_{4}(14)$ before the protein was concentrated 10- to 20-fold with a Centricon microconcentrator (molecular weight cutoff, 10,000; Amicon Corp.).

Gel shift assays. Promoter DNA-protein complexes were formed by incubating 2 to $20 \mathrm{fmol}$ of end-labeled DNA with protein fractions eluted from a heparin-agarose column (see above). End-labeled fragments were prepared by digesting the appropriate promoter subclone with restriction enzymes to liberate the promoter fragment, followed by filling in the free ends with DNA polymerase Klenow fragment in the presence of deoxynucleoside triphosphates and $\left[\alpha-{ }^{32} \mathrm{P}\right] \mathrm{dATP}$ (600 Ci/mmol; New England Nuclear Corp.). Radioactive fragments were purified from $6 \%$ acrylamide gels by electroelution and subsequent precipitation. A 280- to 1,690-fold molar excess of supercoiled pUC19 was included in each incubation to prevent interference from nonspecific DNAbinding proteins present in the extracts.

Binding reactions, carried out essentially as described by Huet et al. (14), were initiated by the addition of protein extract to DNA samples in a final volume of $20 \mu \mathrm{l}$. Binding buffer was $40 \mathrm{mM}$ Tris hydrochloride $(\mathrm{pH} 8)-70 \mathrm{mM} \mathrm{KCl}-5$ $\mathrm{mM} \beta$-mercaptoethanol-0.1 mM disodium EDTA-7\% glycerol $(\mathrm{vol} / \mathrm{vol})$. In preliminary experiments which included $\mathrm{MgCl}_{2}$ and $\mathrm{CaCl}_{2}$, label in DNA appeared to be lost as a result of nuclease activity in the extracts. Omission of $\mathrm{MgCl}_{2}$ and $\mathrm{CaCl}_{2}$ from the binding reaction eliminated this problem without affecting specific binding to TCMI DNA. Binding reactions were incubated for $15 \mathrm{~min}$ at room temperature. Then samples were loaded onto acrylamide gels ( 11 by 13 by $0.15 \mathrm{~cm} ; 4.94 \%$ acrylamide $-0.06 \%$ bisacrylamide) prepared in $40 \mathrm{mM}$ Tris hydrochloride ( $\mathrm{pH} 8$ ) $-1 \mathrm{mM}$ disodium EDTA$5 \%$ glycerol ( $\mathrm{vol} / \mathrm{vol})$. After polymerization, gels were equilibrated with reservoir buffer $[40 \mathrm{mM}$ Tris hydrochloride $(\mathrm{pH}$ 8), $1 \mathrm{mM}$ disodium EDTA] overnight at 0 to $4^{\circ} \mathrm{C}$. Gels were run at $175 \mathrm{~V}(70 \mathrm{~mA})$ for 2 to $4 \mathrm{~h}$ at 0 to $4^{\circ} \mathrm{C}$. Bromophenol blue and xylene cyanol were loaded in side wells to monitor migration.

Photochemical cross-linking. A single-stranded DNA oligomer encompassing the cis-acting element of either rp gene $T C M I$ or $L 25$ was rendered double-stranded with DNA polymerase in the presence of $2.5 \mu \mathrm{M}\left[\alpha^{-32} \mathrm{P}\right] \mathrm{dATP}(600 \mathrm{Ci} /$ mmol) and $50 \mu \mathrm{M}$ each of dCTP, dGTP, and 5-bromo-2' deoxyuridine-5'-triphosphate (Sigma Chemical Co.). Sec- 
ond-strand synthesis was initiated by annealing the universal M13 sequencing primer (28) to its complement included as the $3^{\prime}$ end of each oligomer. Competitor DNA was synthesized in exactly the same manner except that unlabeled dATP replaced $\left[\alpha-{ }^{32} \mathrm{P}\right] \mathrm{dATP}$. The resulting double-stranded DNAs were subjected to G-50 Sephadex column chromatography to remove unincorporated nucleotides. The sequences of the oligonucleotides were as follows: $\mathrm{UAS}_{\mathrm{T}}$-UV, CGC TTCTTGAAAAACGTACAAAACGATTACTACGTCGTG ACTGGGA ( -216 to -186 of TCMI promoter sequence) and $\mathrm{UAS}_{\mathrm{rpg}}-\mathrm{UV}$, GTAAACACCCGTACATATTAAATCA GTGACTACGTCGTGACTGGGA $(-406$ to -378 of the L25 promoter sequence; see reference 50 ). The underlined sequence is native $\mathrm{rp}$ gene sequence. Three base pairs of non- $L 25$ DNA was added between the $3^{\prime}$ end of the $L 25$ sequence and the primer annealing site so that both oligonucleotides had an identical size.

Photochemical cross-linking was carried out as follows. DNA-protein-binding reactions were performed by using the 5-bromo-2'-deoxyuridine, $\left[\alpha-{ }^{32} \mathrm{P}\right] \mathrm{dATP}$-substituted DNA. Half of the sample was examined by gel shift assay to verify protein-binding activity; the other half was placed in a microtiter tray, covered with Saran Wrap, and irradiated for $60 \mathrm{~min}$ at a distance of $1 \mathrm{~cm}$ with a UV lamp (FOTODYNE model $3-6000 ; \lambda_{\max }, 300 \mathrm{~nm}$ ). After irradiation, $\mathrm{MgCl}_{2}$ and $\mathrm{CaCl}_{2}$ were added to $10 \mathrm{mM}$ and $2 \mathrm{mM}$, respectively, and the samples were treated with $0.4 \mu \mathrm{g}$ of DNase I for $20 \mathrm{~min}$ at room temperature. DNase treatment was terminated by the addition of SDS-polyacrylamide gel loading buffer followed by incubation at $100^{\circ} \mathrm{C}$ for $3 \mathrm{~min}$. Samples, along with prestained molecular weight markers (Diversified Biotech), were analyzed on SDS-8\% polyacrylamide gels (22) with $N, N^{\prime}$-diallyltartardiamide substituted for bisacrylamide. Gels were dried and subjected to autoradiography.

Footprinting. (i) DNase I. Protein-DNA-binding reactions were conducted as described above; complexes were formed with protein extract sufficient to bind $>90 \%$ of the DNA. After incubation, $\mathrm{MgCl}_{2}$ and $\mathrm{CaCl}_{2}$ were added to final concentrations of $10 \mathrm{mM}$ and $2 \mathrm{mM}$, respectively. DNase I (10 U; Bethesda Research Laboratories) was added and incubation was continued for $1 \mathrm{~min}$ at room temperature. The reaction was terminated by the addition of disodium EDTA to $50 \mathrm{mM}$. Samples were extracted successively with phenol and chloroform; the DNA was precipitated with ethanol, rinsed with $70 \%$ ethanol, and loaded onto $6 \%$ sequencing gels (for $\sim 400$-bp fragments) or $8 \%$ sequencing gels (for $\sim 90$-bp fragments). Maxam-Gilbert sequencing reactions (27) performed on the same end-labeled DNA fragment were run as markers. The gels were dried and subjected to autoradiography.

(ii) Methidiumpropyl-Fe(II)-EDTA (MPE). Binding reactions were carried out as above but scaled up to $50 \mu \mathrm{l}$. After incubation, methidiumpropyl-EDTA and $\mathrm{FeNH}_{4}\left(\mathrm{SO}_{4}\right)_{2}$ were added to a final concentration of $10 \mathrm{mM}(16,45)$. DNA cleavage was initiated by the addition of dithiothreitol to 2 $\mathrm{mM}$. After $25 \mathrm{~min}$ at $25^{\circ} \mathrm{C}$, reactions were terminated by extraction with phenol. From this point samples were treated as for DNase I footprinting.

\section{RESULTS}

The transcriptional activation region of $T C M 1$. The region upstream of $T C M I$ responsible for transcriptional activation was delimited from a series of progressive promoter deletions. To monitor their effects, each deletion construct was joined to the $E$. coli $\beta$-galactosidase (lacZ) coding sequence

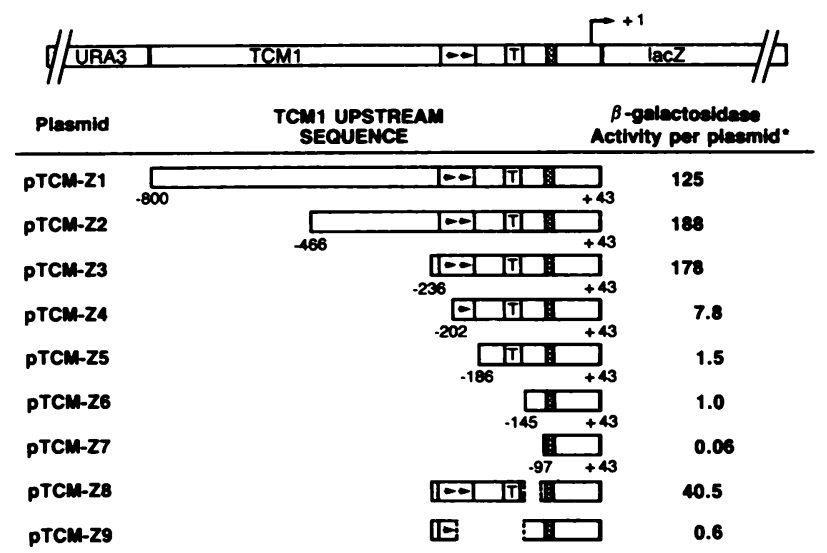

$$
\begin{aligned}
-\nabla & =\text { TCM1 UPSTREAM ACTIVATION SEOUENCE } \\
\square & =\text { T-rich region } \\
\mathbf{\theta} & =\text { presumptive TATA BOX }
\end{aligned}
$$

FIG. 1. Effects of promoter deletions on expression of TCMI. Segments of yeast rp gene $T C M 1$, each extending from 43 bases $3^{\prime}$ of the transcription start site upstream to the various positions indicated, were inserted between the $3^{\prime}$ end of the yeast $U R A 3$ gene and the amino terminus of the $E$. coli $\beta$-galactosidase gene (lacZ), placing $T C M I$ in a continuous translational reading frame with $l a c Z$. The constructs, contained in the multicopy plasmid pLG669-ZX (see Materials and Methods), were introduced into $S$. cerevisiae; expression of $l a c Z$ driven by the various $T C M I$ promoters was quantitated by measuring $\beta$-galactosidase activity in cell extracts. Note that plasmids pTCM-Z8 and pTCM-Z9 were identical to pTCM-Z3 except that pTCM-Z8 lacked sequence between -97 and -145 while pTCM-Z9 lacked sequence between -145 and -186 . $^{*}$ All results for $\beta$-galactosidase activity are presented normalized to a plasmid copy number of 1 . Actual plasmid copy numbers, measured as described in Materials and Methods, were: pTCM-Z1, 12; pTCMZ2, 9; pTCM-Z3, 9; pTCM-Z4, 5; pTCM-Z5, 15; pTCM-Z6, 15; pTCM-Z7, 8; pTCM-Z8, 19; pTCM-Z9, 5.

at the fifth codon of $T C M 1$. Figure 1 shows the results of $\beta$-galactosidase assays for extracts of yeast cells carrying the various hybrid genes within multicopy plasmids. The results, normalized to a plasmid copy number of 1 (see Materials and Methods), are summarized as follows. Deletions which retained $236 \mathrm{bp}$ or more upstream of $T C M 1$ gave high levels of expression (plasmids pTCM-Z1, $-\mathrm{Z2}$, and $-\mathrm{Z3}$ ). However, deletion of an additional 34 bp (to -202 in pTCM-Z4) diminished transcriptional activity to $\sim 6 \%$ of normal. A further deletion of $16 \mathrm{bp}$ reduced expression to $\sim 1 \%$ (pTCMZ5), while expression was undetectable from constructs containing only 145 or 97 bp of upstream sequence (pTCM$\mathrm{Z6}$ and $-\mathrm{Z7}$ ). None of the deletions altered the selection of TCMI transcription initiation sites (data not shown).

These results suggested that efficient transcription of TCMI required sequences located between 236 and $145 \mathrm{bp}$ upstream of its start site. Since removal of the 5'-most $34 \mathrm{bp}$ of this region lowered expression by $>90 \%$, we asked whether the 34-bp segment alone would bring about transcription. This question was especially pertinent because the 34-bp segment contained one of three repeated sequences $\left(\mathrm{C} / \mathrm{T}\right.$ GTTTTN $/ \mathrm{T}^{\mathrm{A}}$ ) that occur between -236 and -145 (see Fig. 12 and Discussion); often eucaryotic promoters consist of reiterations of a particular cis-acting sequence (42). To test the activity of the 34-bp segment, we deleted the DNA between -202 and -145 , leaving only those 34 bp (see pTCM-Z9 in Fig. 1); however, no expression was detected from this construct. As demonstrated below, this 34-bp 


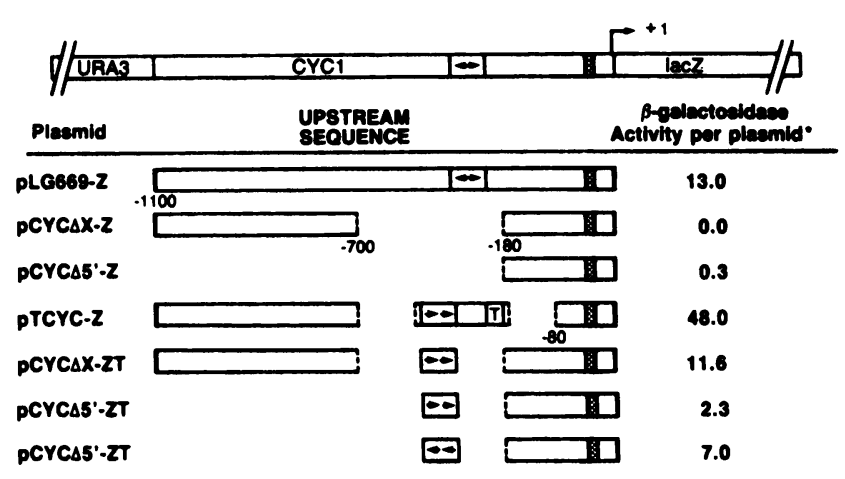

$$
\begin{aligned}
& \phi=\text { CYCI UPSTREAM ACTIVATION SEQUENCE } \\
& \theta=\text { TCMI UPSTREAM ACTIVATION SEOUENCE } \\
& \text { T] = T-rich region } \\
& =\text { TATA BOX }
\end{aligned}
$$

FIG. 2. Activation of CYCl-lacZ gene by $\mathrm{UAS}_{\mathrm{T}}$. Plasmid pLG669-Z contained a segment of yeast $C Y C 1$, extending from $\sim 1,100 \mathrm{bp} 5^{\prime}$ to $15 \mathrm{bp} 3^{\prime}$ of the start site, inserted between $U R A 3$ and $E$. coli lacZ. Gaps in other plasmid diagrams show regions deleted from $C Y C I$. pTCYC-Z contained an insertion of a 91-bp segment encompassing $\mathrm{UAS}_{\mathrm{T}}$ and the T-rich region of TCMI. pCYCDX-ZT and $\mathrm{pCYC} \Delta 5^{\prime}-\mathrm{ZT}$ contained insertions of the 19-bp UAS (inserted $_{\mathrm{T}}$ in both orientations in pCYC $\left.\Delta 5^{\prime}-\mathrm{ZT}\right) .{ }^{*}$ Actual plasmid copy numbers were: pLG669-Z, 15; pCYC $\Delta X-Z$, not determined; pCYC $\Delta 5^{\prime}$ Z, 26; pTCYC-Z, 3; pCYC $\Delta X-Z T, 3$; pCYC $\Delta 5$ '-ZT, 12.

segment failed to promote transcription because it constituted only a portion of the sequence necessary for most of the transcriptional activity of $T C M 1$.

The results discussed above showed that nucleotide residues located between 236 and 145 bp upstream of the TCMI start site were probably sufficient to promote transcription. To exclude the possibility that elements in this region cooperate with sequences closer to the transcription start site, we deleted the region between -145 and -97 from a construct originally containing DNA extending to -236 (pTCMZ-8 in Fig. 1); the -97 endpoint is immediately upstream of the most likely TATA homology of TCMI (see Fig. 12). The promoter resulting from this internal deletion retained about $30 \%$ transcriptional activity. This result could be interpreted as suggesting that the region between -236 and -145 was not entirely sufficient for transcription; alternatively, the $-236 /-145$ region could be sufficient, but once the DNA between it and the TATA box was eliminated (in pTCMZ-8) the two regions may have become situated on different sides of the DNA helix and unable to cooperate (39). We have not addressed this uncertainty; nonetheless, as described next, the $-236 /-145$ region did function as an efficient transcriptional activator when positioned upstream of a heterologous gene, so that if this segment was acting in concert with other promoter elements, those other elements are not confined to $T C M I$.

Independence of $T C M I$ upstream region. Before refining further the limits of the $T C M I$ activation region, we tested the ability of the $91-b p-236 /-145$ segment to activate transcription of another gene, as cross-activation is a property common among transcriptional activation elements (42). The 91-bp segment of TCMI was inserted upstream of the yeast $C Y C l$ gene (encoding iso-1-cytochrome $c$ ), simultaneously replacing all of the DNA normally required for $C Y C 1$ activation. Figure 2 shows that when joined to $l a c Z$,

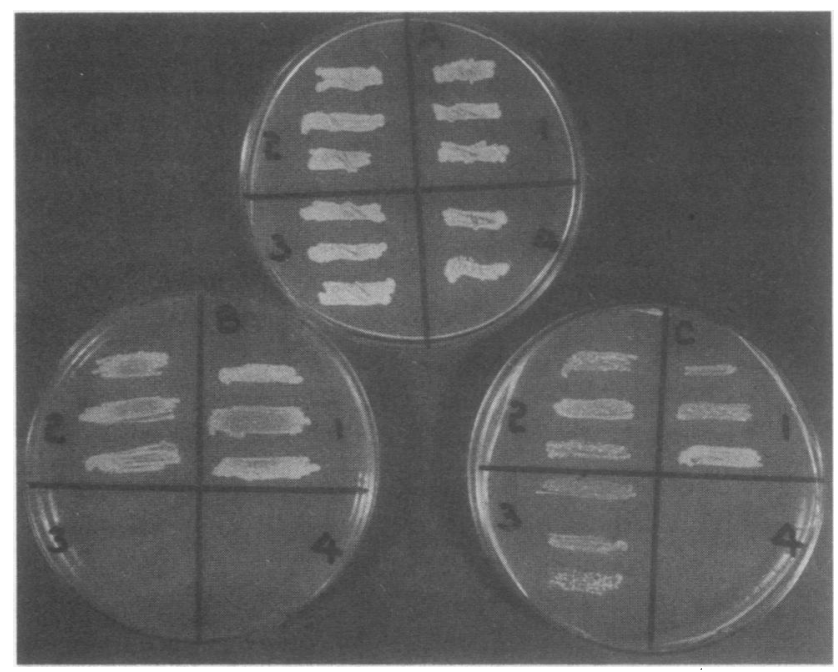

FIG. 3. Complementation of a $c y c l c y c 7$ yeast strain by a $C Y C l$ gene containing the upstream activation region of $T C M I$ in place of the $\mathrm{CYCl}$ upstream activation region. Plate A contained $2 \%$ glucose, plate B contained $2 \%$ lactate, and plate $\mathrm{C}$ contained $3 \%$ glycerol. Cytochrome $c$ (product of $C Y C l$ ) is required for growth on the latter two carbon sources. On each plate were cells transformed with a plasmid carrying a complete $C Y C I$ gene (quadrant 1); pTCYC, the same TCMI-CYCI promoter fusion as in Fig. 2 but with lacZ replaced by $C Y C l$ (quadrant 2); pCYC $\triangle \mathrm{X}$, a $C Y C I$ plasmid lacking the $C Y C l$ activation region (analogous to pCYC $\Delta \mathrm{X}-\mathrm{Z}$ in Fig. 2) (quadrant 3); a control plasmid without any $C Y C l$ gene (quadrant 4). Note that pCYC $\triangle \mathrm{X}$, a $C Y C 1$ deletion from -180 to -700 (see Materials and Methods), was transcribed at a low level, enough to permit growth on glycerol but not lactate. Plasmid pTCYC without the $T C M 1$ activation region (not shown), and thus a $C Y C l$ deletion from -80 to -700 , did not support growth on either carbon source.

the TCMI-CYCl hybrid promoter (in pTCYC-Z) produced as much or more $\beta$-galactosidase as an intact $C Y C l$ promoter similarly joined to lacZ (in pLG669-Z). As a further demonstration of cross-activation, we joined the TCMI-CYCl hybrid promoter to the entire $C Y C l$ coding sequence (in pTCYC) and introduced the hybrid gene into a yeast strain lacking functional $C Y C 1$ and $C Y C 7$ genes, which contribute $95 \%$ and $5 \%$ of the cell's cytochrome $c$, respectively. The recipient strain was unable to grow on nonfermentable carbon sources because of an absence of an intact electron transport chain. Figure 3 shows that the TCMI-CYCI hybrid promoter adjacent to $C Y C l$ led to a restoration of cytochrome $c$ synthesis, as evidenced by growth of the plasmidbearing strain on glycerol. Furthermore, sufficient cytochrome $c$ was produced for the cells to grow on lactate, which requires not only an intact electron transport chain but at least $30 \%$ of the wild-type amount of cytochrome $c$ (20). These results demonstrated that the -236 to -145 segment of TCMI functioned as an independent transcriptional activator.

Initial identification of TCMI DNA-binding activity. Although sufficient to promote transcription in an autonomous manner, the 91-bp segment between -145 and -236 was relatively large. Therefore, we sought to define more narrowly a transcriptional activation sequence by first identifying a potential transcription factor (or factors) that bound specifically to a smaller portion of the $91-b p$ region. Specific binding to the promoter region of TCMI was detected by incubating a yeast protein extract, subjected to heparinagarose column chromatography $(14,37$; see Materials and Methods), with the same deletion fragments used to measure 


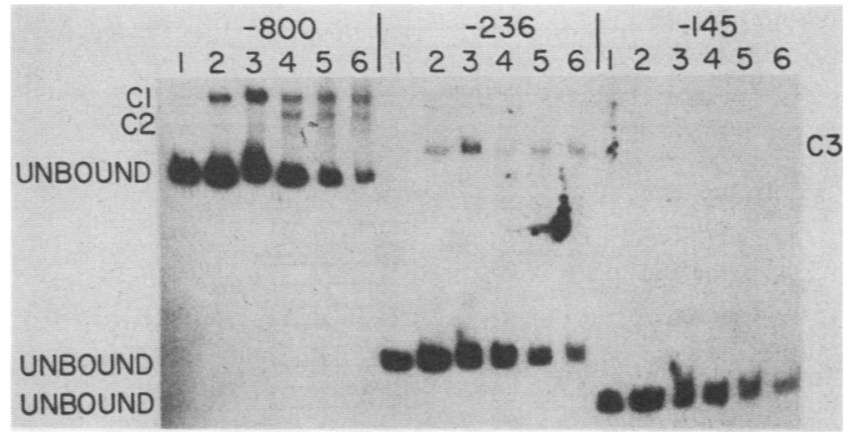

FIG. 4. Gel shift assay using promoter deletions to localize TAF binding site. Binding reactions were carried out with $5 \mathrm{fmol}$ of one of three probes: an $\mathbf{- 8 0 0}$ promoter fragment from pUC-Z1, a -236 promoter fragment from pUC-Z3, and a -145 promoter fragment from pUC-Z6 (the actual sizes of each fragment used in the binding reactions were $43 \mathrm{bp}$ larger than the values given atop the figure, as the DNA segments extended into the $T C M I$ coding sequence; see Materials and Methods). Also included in the binding reactions was $280 \mathrm{fmol}$ of pUC19 DNA. The protein extracts used in the binding reactions were as follows: lane 1 , no protein added; lanes 2 and 3, 0.5 and $1.0 \mu \mathrm{g}$ of protein from the $0.1 \mathrm{M}\left(\mathrm{NH}_{4}\right)_{2} \mathrm{SO}_{4}$ elution of a heparin-agarose column (see Materials and Methods); lanes 4, 5, and $6,0.5,1.0$ and $1.5 \mu \mathrm{g}$ of protein from the pooled fractions eluted with 0.25 and $0.5 \mathrm{M}\left(\mathrm{NH}_{4}\right)_{2} \mathrm{SO}_{4} . \mathrm{C} 1$ and $\mathrm{C} 2$ indicate specific DNA-protein complexes formed with the $-\mathbf{8 0 0}$ promoter fragment; $\mathrm{C} 3$ indicates a complex with the -236 fragment. No complex was observed with the -145 fragment.

expression in vivo. Formation of protein DNA complexes was inferred from reduced mobility of the labeled DNA (relative to free DNA) in nondenaturing polyacrylamide gels (9). Figure 4 shows the results of a gel shift assay using three promoter fragments subcloned into pUC19. Presumptive DNA-protein complexes were observed with the two larger promoter fragments from $\mathrm{pUC}-\mathrm{Z1}$ and $\mathrm{pUC}-\mathrm{Z3}$ containing the 91-bp transcriptional activation sequence but not with the smaller fragment from pUC-Z5 that lacked these $91 \mathrm{bp}$. DNA fragments of equivalent size and unrelated to TCMI also did not bind to protein in the extract (data not shown).

These results for protein binding to promoter segments of TCMI paralleled the transcriptional activity of those segments in vivo. The promoter fragments from pUC-Z1 and pUC-Z3 truncated at -800 or -236 , respectively, supported both protein binding and maximum transcription in vivo (see pTCM-Z1 and pTCM-Z3 in Fig. 1), while the fragment derived from pUC-Z6 truncated at -145 sustained neither binding nor transcription (see pTCM-Z6 in Fig. 1). We also found protein binding to a fragment consisting of only the 91-bp transcriptional activation region of TCMI (see Fig. 6). In summary, these results suggested that binding in vitro reflected the interaction of a transcription factor with the TCMI promoter. We designated this factor TAF (TCMI activation factor).

The fragment from pUC-Z1 that contained sequence extending $800 \mathrm{bp}$ upstream of $T C M 1$ generated two proteinDNA complexes ( $\mathrm{C} 1$ and $\mathrm{C} 2$ in Fig. 4) while the fragment from pUC-Z3, extending only 236 bp upstream of $T C M I$, produced but a single complex (C3). Since sequence beyond -236 was not necessary for TCMI expression, formation of multiple protein-DNA complexes with the -800 fragment may have resulted from protein binding to an adjacent gene. However, additional transcripts have not been detected by using the -800 -bp fragment as a probe, minimizing the likelihood that another gene was adjacent to TCMI within

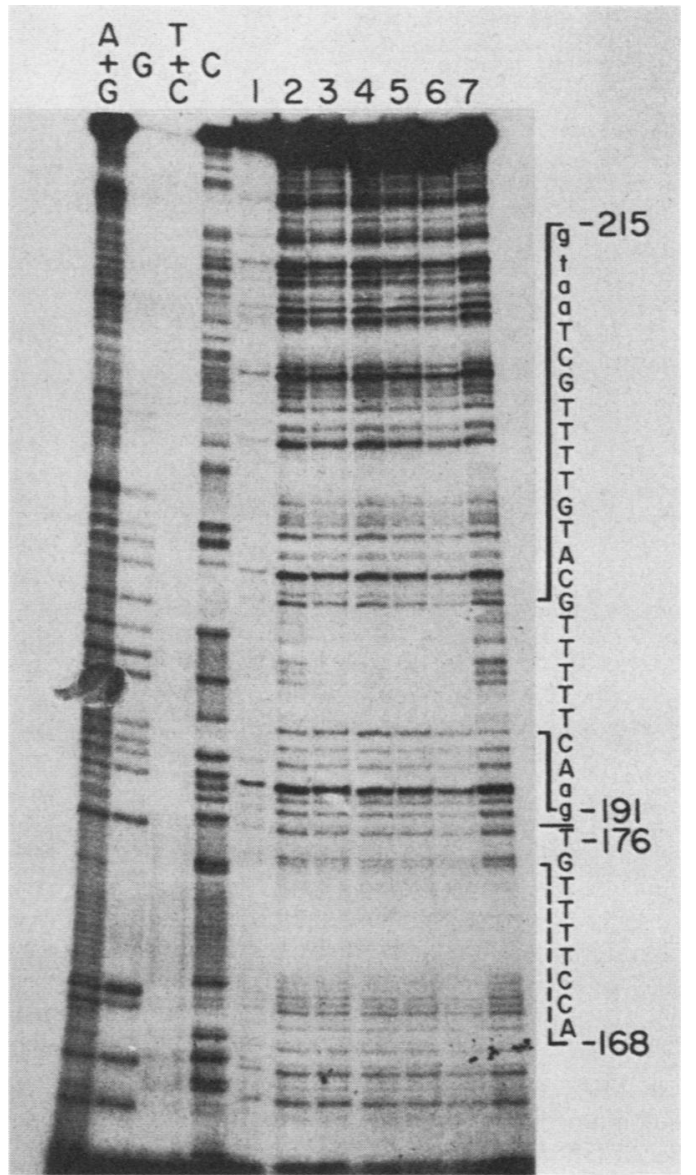

FIG. 5. DNase I footprint analysis of TCMI-TAF complex. Plasmid pUC-Z3 contained a 279-bp fragment of TCMI, extending from -236 to +43 , inserted in the pUC19 polylinker. The plasmid was cleaved at an $X b a I$ site that occurs at -10 in the $T C M I$ fragment and labeled by fill-in synthesis with DNA polymerase in the presence of $\left[\alpha-{ }^{32} \mathrm{P}\right] \mathrm{dATP}$. The labeled TCMI fragment $(5 \mathrm{fmol})$ was liberated from the plasmid by digestion with HindIII in the polylinker, purified and incubated with sufficient protein extract to yield $>90 \%$ binding to TAF, digested briefly with DNase I, and subjected to electrophoresis in a denaturing sequencing gel (see Materials and Methods). Lanes: 1 and 7, DNA incubated without protein extract; 2 through 6, DNA incubated with $1.03,3.09,5.15,8.24$, and $10.3 \mu \mathrm{g}$ of protein extract, respectively. The lettered lanes are MaxamGilbert sequencing reactions. The sequence protected from DNase I digestion is shown alongside; numbers refer to base pairs from transcription start site $(+1)$. $\mathrm{UAS}_{\mathrm{T}}$ is indicated by uppercase letters. Dotted lines show a sequence related to the repeat unit in $\mathrm{UAS}_{\mathrm{T}}$ but which did not produce a footprint. A complete sequence of the TCMI promoter region is shown in Fig. 12.

the -800 -bp fragment. On the other hand, we show below that the 5 ' boundary of the TAF-binding site was very close to the end of the -236-bp segment, at -211 . Perhaps protein binding near -211 facilitated binding of additional polypeptides upstream of this region, thus accounting for the formation of multiple DNA-protein complexes with the -800 -bp fragment.

Footprinting. Two DNA footprinting techniques were used to identify the TAF binding site within the TCMI promoter. Figure 5 shows a result for DNase I footprinting in which the coding strand of $T C M I$ was labeled. A segment of 25 bp spanning the region between -191 and -215 was protected from DNase I cleavage. The sequence of this 


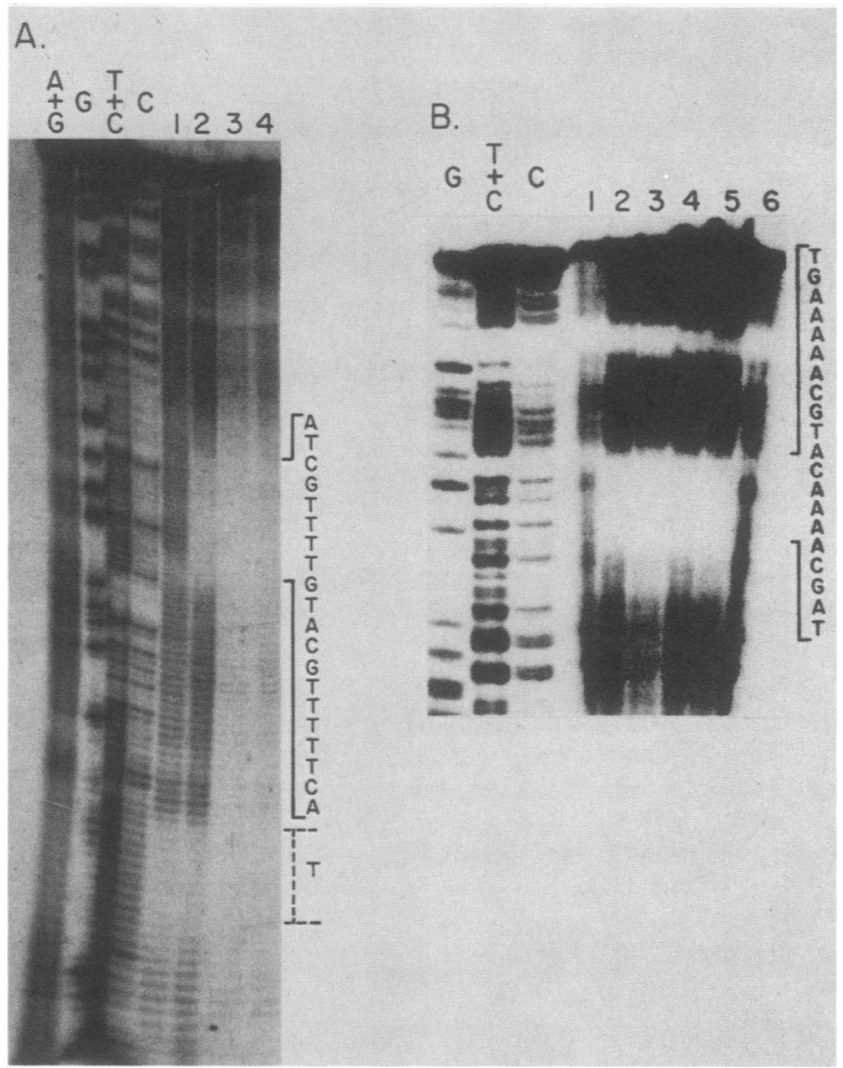

FIG. 6. MPE footprint analysis of TCMI promoter. Plasmid pUC-Z8 contained a 91-bp fragment of $T C M I$, extending from -146 to -236. (A) The coding strand of this fragment was labeled by filling in the HindIII site of the polylinker ' $3^{\prime}$ of the TCMI sequence. Lanes 1 through 4 , DNA incubated with $0,5.15,20.6$, and $28.3 \mu \mathrm{g}$ of protein extract, respectively. (B) The complementary strand was labeled at the $3^{\prime}$ end by filling in the EcoRI site in the pUC polylinker. Lanes 1 through 6, DNA incubated with $0,2.06,5.15$, $10.3,20.6$, and $0 \mu \mathrm{g}$ of protein extract, respectively. The respective footprints are shown alongside the figure. The region indicated by $T$ and the dotted brackets shows the location of a stretch of 18 consecutive T's centered at -160 in TCMI ; such T-stretches are relatively refractory to cleavage by MPE due to narrowing of the minor groove (5).

region contained the two nearly perfect 9-bp repeats first noticed in regard to the analysis of promoter deletions (see above). Interestingly, another single 9-bp sequence similar to the two adjacent repeats is located more proximal to the TCMI transcription start site (Fig. 5; see Fig. 12); however, even at higher protein concentrations, no protection was seen of this other single 9-bp sequence.

We confirmed the DNase I footprint by cleaving DNAprotein complexes with MPE $(16,45)$. Since MPE is a smaller molecule with less sequence preference than DNase I, a smaller footprint was expected. Footprinting of both strands of TCMI with MPE showed a 19- to 20-bp protected segment within the 25 bp revealed by DNase I footprinting (Fig. 6).

The TAF-binding site revealed by DNA footprinting was consistent with TAF being a transcriptional activator protein, since the footprinted sequence was contained within a region necessary for transcription. As shown above, promoter deletions that included all or part of the 19-bp TAF binding site diminished transcription to $6 \%$ or less than normal (pTCM-Z4 and pTCM-Z5 in Fig. 1).

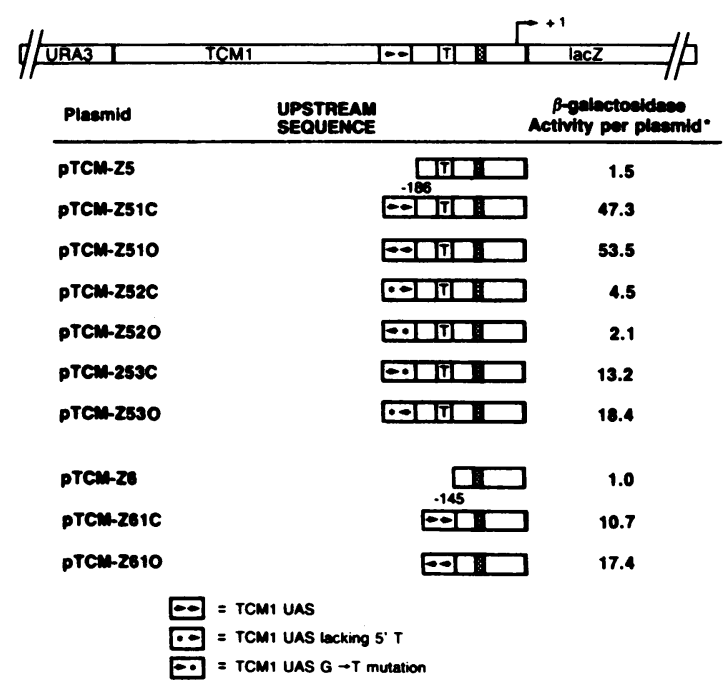

FIG. 7. Activation of TCMI promoter deletions by wild-type and altered versions of $\mathrm{UAS}_{\mathrm{T}}$. Plasmids pTCM-Z5 and $-\mathrm{Z6}$ were the same as in Fig. 1. A single copy of $\mathrm{UAS}_{\mathrm{T}}$ was inserted into each plasmid, in both orientations $(\mathrm{C}$, usual orientation found in $T C M I$; $\mathrm{O}$, opposite orientation), immediately upstream of the deletion endpoints -186 (pTCM-Z5) and -145 (pTCM-Z6). Note that UAS normally resides between -192 and -211 . Likewise, a version of UAS $_{\mathrm{T}}$ lacking its $5^{\prime}$-most nucleotide as well as one in which the T at position 15 was changed to a $G$ was inserted into pTCM-Z5 in both orientations. * Plasmid copy numbers were as follows: pTCM-Z5, 15; pTCM-Z51C, 18; pTCM-Z51O, 21; pTCM-Z52C, 17; pTCMZ52O, 13; pTCM-Z53C, 18; pTCM-Z53O, 20; pTCM-Z6, 15; pTCMZ61C, 21; pTCM-Z61O, 15.

A 19-bp sequence activates TCMI transcription. The DNA footprinting experiments coupled with analysis of promoter deletions suggested that the 19- to 20-bp TAF binding site was a potential transcriptional activation sequence. To ascertain whether this binding site, which we designated $\mathrm{UAS}_{\mathrm{T}}$ (TCMI upstream activation sequence) was sufficient to support transcription on its own, we synthesized a 19-bp doublestranded DNA oligomer corresponding to $\mathrm{UAS}_{\mathrm{T}}$ and exchanged a single copy of this 19-mer for the entire activation region of either $C Y C 1$ or $T C M I$. Figures 2 and 7 show the results of these constructs. In plasmid pCYCA5'-ZT, the $\mathrm{UAS}_{\mathrm{T}}$ element was inserted 180 bp upstream of the $C Y C I$ start site, resulting in about an 8-fold stimulation of expression when placed in its usual orientation and about 23 -fold stimulation when inserted in the opposite orientation (compared with pCYC $\Delta 5^{\prime}-\mathrm{Z}$, the same plasmid lacking $U A S_{\mathrm{T}}$ ). Better activation, about 38-fold, was observed in pCYC $\Delta \mathrm{X}$ ZT which contained UAS TA $_{\mathrm{T}}$ at the same -180 location in CYCl. In this case, 400 bp of DNA separated $\mathrm{UAS}_{\mathrm{T}}$ from the $3^{\prime}$ end of the URA3 gene common to all the plasmids, whereas in pCYC $\Delta 5^{\prime}-\mathrm{ZT}, \mathrm{UAS}_{\mathrm{T}}$ was immediately adjacent to the $U R A 3$ transcription termination region; possibly the close apposition of transcription termination and initiation regions interfered with transcription of $C Y C 1$ in pCYC $\triangle 5^{\prime}$ ZT.

Similar activation resulted from placement of $\mathrm{UAS}_{\mathrm{T}}$ adjacent to TCM1. When placed in its usual orientation, insertion of $\mathrm{UAS}_{\mathrm{T}}$ at -186 of $T C M 1$ restored transcription to $38 \%$ of normal while insertion in the opposite orientation restored transcription to $43 \%$ of normal (Fig. 7; pTCM-Z51C and Z51O). Likewise, while not achieving nearly as high a level of expression, insertion of $\mathrm{UAS}_{\mathrm{T}} 145 \mathrm{bp}$ upstream of TCMI did yield reproducible increases of 8 to $14 \%$ (Fig. 7; pTCM- 


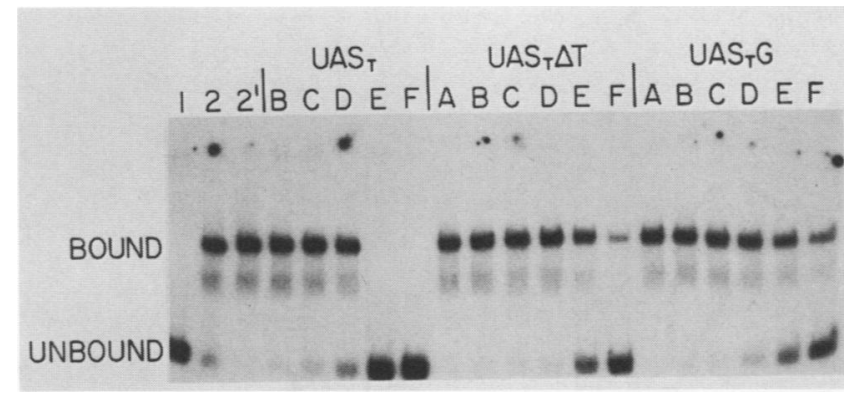

FIG. 8. Competition gel shift assay of wild-type and mutant $\mathrm{UAS}_{\mathrm{T}}$ sequences. Mutant $\mathrm{UAS}_{\mathrm{T}}$ sequences, $\mathrm{UAS}_{\mathrm{T}} \Delta \mathrm{T}$ and $\mathrm{UAS}_{\mathrm{T}} \mathrm{G}$ were compared in their affinity for TAF, relative to the wild-type $\mathrm{UAS}_{\mathrm{T}}$ sequence. DNA-protein complexes were formed with a ${ }^{32} \mathrm{P}$-labeled wild-type $\mathrm{UAS}_{\mathrm{T}}$ probe (from pUC-Z3; $4 \mathrm{fmol}$ ) in the presence of the specific supercoiled competitor plasmids containing $\mathrm{UAS}_{\mathrm{T}}, \mathrm{UAS}_{\mathrm{T}} \Delta \mathrm{T}$, or $\mathrm{UAS}_{\mathrm{T}} \mathrm{G}$ sequences. Lanes 1,2 , and $2^{\prime}$ contained ${ }^{32} \mathrm{P}$-labeled DNA, incubated without specific competitor DNA, in the presence of $0,0.27$, and $0.54 \mu \mathrm{g}$ of protein extract, respectively. All other binding reactions contained $0.54 \mu \mathrm{g}$ of extract. Lanes A contained a 1-fold molar excess and lanes B through $\mathrm{F}$ contained 2-, 5-, 10-, 50-, and 100-fold molar excesses, respectively, of competitor DNA. All binding reactions also contained $560 \mathrm{fmol}$ of nonspecific competitor pUC19 DNA.

Z61C and -Z61O). Less expression from these latter constructs was probably due to their lacking the T-rich region immediately $5^{\prime}$ of -145 (see Fig. 12); such T-rich stretches are typical of yeast promoters and necessary for optimal transcription $(36,42)$. In any case, from these results for activation of $T C M I$ and those described above for $C Y C I$, we concluded that $\mathrm{UAS}_{\mathrm{T}}$ is the principal cis-acting element of $T C M I$ constitutive transcription.

Finally, the function of $\mathrm{UAS}_{\mathrm{T}}$ was confirmed by finding that single-base-pair alterations introduced into its sequence resulted in reduced transcriptional activation. Whereas insertion of the 19-bp $\mathrm{UAS}_{\mathrm{T}}$ at -186 (in pTCM-Z5) restored transcription to $\sim 40 \%$ of normal, a double-stranded $\mathrm{UAS}_{\mathrm{T}}$ oligomer lacking the 5'-most base pair sustained transcription at only about 3\% of normal (Fig. 7; pTCM-Z52C and -Z52O). Similarly, changing the $T$ to a $G$ in position 15 of UAS $_{\mathbf{T}}$ yielded an oligomer capable of only one-third the transcriptional activity of the wild-type sequence (Fig. 7; pTCM-Z53C and -Z53O).
Interaction of TAF with altered $\mathrm{UAS}_{\mathrm{T}}$ sequences. The results presented to this point have shown that $\mathrm{UAS}_{\mathrm{T}}$ was both a transcriptional activation sequence and an in vitro binding site for TAF. If indeed in vitro binding of TAF reflected a requirement for this protein in transcription, then nucleotide alterations in $\mathrm{UAS}_{\mathrm{T}}$ that diminished transcription should be mirrored by reduced binding of TAF. Therefore, we measured the interaction of TAF with the two altered versions of $\mathrm{UAS}_{\mathrm{T}}$ found to be impaired in transcription.

The affinity of TAF for altered $\mathrm{UAS}_{\mathrm{T}} \mathrm{S}$ was assessed by measuring the relative effectiveness of the two mutant sequences, here designated $\mathrm{UAS}_{\mathrm{T}} \Delta \mathrm{T}$ and $\mathrm{UAS}_{\mathrm{T}} \mathrm{G}$, as well as the wild-type sequence in competing with a labeled (wildtype) $\mathrm{UAS}_{\mathrm{T}}$ fragment for binding to TAF. As shown in Fig. 8 , neither mutant sequence was as effective a competitor as the wild-type sequence. Relative competitiveness was quantitated by densitometric scanning of the gel, the results of which are given in Table 1 . As expected, a 50-fold molar excess of unlabeled wild-type UAS $_{\mathrm{T}}$ DNA was sufficient to completely prevent TAF binding to the probe. The same excess of $\mathrm{UAS}_{\mathrm{T}} \Delta \mathrm{T}$ was only $30 \%$ as effective a competitor while a 50 -fold molar excess of $\mathrm{UAS}_{\mathrm{T}} \mathrm{G}$ was $37 \%$ as efficient. Nearly complete competition was achieved with a 100 -fold excess of $\mathrm{UAS}_{\mathrm{T}} \Delta \mathrm{T}$, but the same excess of $\mathrm{UAS}_{\mathrm{T}} \mathrm{G}$ was still capable of only $55 \%$ competition. These results were actually opposite to our expectations based on transcriptional activity, since $\mathrm{UAS}_{\mathrm{T}} \Delta \mathrm{T}$ competed better than $\mathrm{UAS}_{\mathrm{T}} \mathrm{G}$ in vitro but in vivo $\mathrm{UAS}_{\mathrm{T}} \Delta \mathrm{T}$ (contained in pTCM-Z52) was less effective than $\mathrm{UAS}_{\mathrm{T}} \mathrm{G}$ (in pTCM-Z53) in transcriptional activation. Nonetheless, mutations in $\mathrm{UAS}_{\mathrm{T}}$ that diminished transcription were associated with reduced binding of TAF in vitro, strengthening the conclusion that TAF is required for transcription of TCMI.

Comparison of TAF with protein binding to $\mathrm{UAS}_{\mathrm{rpg}}$. Transcription of most yeast $\mathrm{rp}$ genes is probably mediated by TUF, a protein which binds to conserved rp promoter sequences referred to collectively as $\operatorname{UAS}_{\mathrm{rpg}}(25,36,40,46$, $50,51)$. Comparison of the sequences of UAS $S_{\mathrm{T}}$ and $U A S_{\text {rpg }}$ showed no obvious relationship between the two protein binding sites, suggesting that TAF and TUF were different polypeptides. To determine whether the two factors were embodied in different proteins, we assayed $\mathrm{UAS}_{\mathrm{T}}$ and $\mathrm{UAS}_{\mathrm{rpg}}$ binding activities present in a yeast cell extract eluted from heparin-agarose with a linear gradient of $\left(\mathrm{NH}_{4}\right)_{2} \mathrm{SO}_{4}$.

TABLE 1. Comparison of transcriptional activation and protein binding between wild-type and altered $U_{A} S_{\mathrm{T}}$ sequences

\begin{tabular}{|c|c|c|c|c|c|c|}
\hline \multirow{2}{*}{ Plasmid } & \multirow{2}{*}{$\mathrm{UAS}_{\mathrm{T}}$ sequence ${ }^{a}$ (coding strand) } & \multirow{2}{*}{$\begin{array}{l}\text { \% Transcriptional } \\
\text { activation }^{b}\end{array}$} & \multicolumn{2}{|c|}{$\begin{array}{l}\% \text { Bound }{ }^{c} \text { at molar } \\
\text { excess: }\end{array}$} & \multicolumn{2}{|c|}{$\begin{array}{c}\% \text { Inhibition }{ }^{d} \text { at molar } \\
\text { excess: }\end{array}$} \\
\hline & & & 50 -fold & 100-fold & 50-fold & 100 -fold \\
\hline pTCM-Z5 & None & 3 & & & & \\
\hline pTCM-Z5UAS $_{\mathrm{T}}$ & TCGTTTTGTACGTTTTTCA & 100 & 0 & $\mathbf{0}$ & 100 & 100 \\
\hline $\operatorname{pTCM}-Z 5 U A S_{T} \Delta T$ & aCGTTTTGTACGTTTTTCA & 9 & 70 & 22 & 30 & 88 \\
\hline pTCM-Z5UAS $_{\mathrm{T}} \mathrm{G}$ & TCGTTTTGTACGTTgTTCA & 28 & 63 & 45 & 37 & 55 \\
\hline
\end{tabular}

$a$ The table shows the sequences of the wild-type and mutant UAS oligomers that were cloned into plasmid pTCM-Z5 (Fig. 1). pTCM-Z5 contained a fragment of TCMI joined at its $3^{\prime}$ end to $E$. coli $\beta$-galactosidase and truncated 186 bp $5^{\prime}$ of the transcription start site. The various UAS Themers were inserted at this

-186 site $\left(\right.$ UAS $_{\mathrm{T}}$ ordinarily resides between -193 and -211$)$. UAS $\mathrm{T}$ T is the same as UAS $\mathrm{T}_{\mathrm{T}}$ except that the $5^{\prime}$-most T was omitted. The lower case "a" at the

5 ' end of the UAS $\mathrm{T}_{\mathrm{T}} \Delta \mathrm{T}$ sequence indicates the nucleotide that occupied that position after insertion into pTCM-Z5. The lower case " $\mathrm{g}$ " in the UAS $\mathrm{T}_{\mathrm{T}} \mathrm{G}$ sequence indicates that the $T$ normally at this position has been replaced by a $G$.

$b$ The transcriptional activities of the various plasmids were assessed from measurements of $\beta$-galactosidase activity. For convenience in comparisons, the

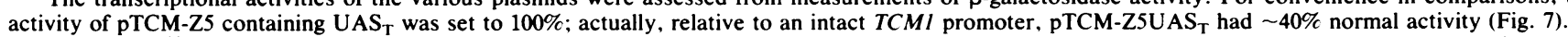

c Amount of ${ }^{32} \mathrm{P}$-labeled wild-type UAS $\mathrm{UA}_{\mathrm{T}}$ sequence that bound to protein in the presence of a 50- or 100-fold molar excess of unlabeled DNA fragments containing, respectively, $\mathrm{UAS}_{\mathrm{T}}, \mathrm{UAS}_{\mathrm{T}} \Delta \mathrm{T}$, or $\mathrm{UAS}_{\mathrm{T}} \mathrm{G}$. The $\%$ bound was determined from densitometric quantitation of the autoradiographic intensities of the bound and unbound bands in Fig. 8, lanes 7 and 8,13 and 14, and 19 and 20.

${ }^{d}$ Relative effectiveness of each $\mathrm{UAS}_{\mathrm{T}}$ sequence in preventing protein from binding to the ${ }^{32} \mathrm{P}$-labeled wild-type UAS $\mathrm{T}_{\mathrm{T}}$ sequence, i.e., $100 \%$ minus the percent that bound. 

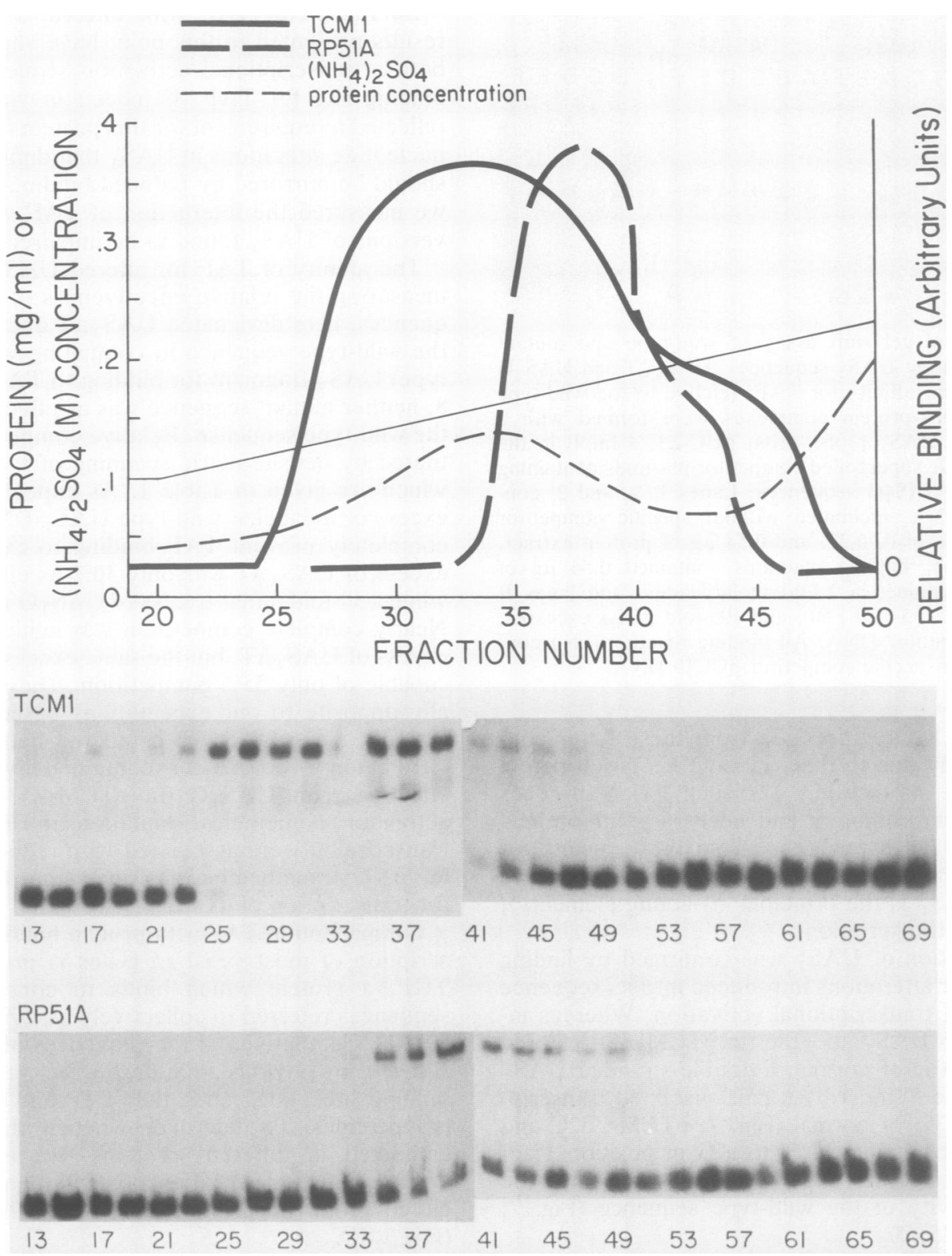

FIG. 9. Column profiles for TAF (TCMI) and TUF (RPSIA) binding activities. Heparin-agarose column fractions eluted with a gradient of $\left(\mathrm{NH}_{4}\right)_{2} \mathrm{SO}_{4}$ (see Materials and Methods) were assayed for proteins binding to rp genes. Every other fraction was screened by gel shift assay using as probes either a $T C M I$ fragment extending from -236 to $+43(4 \mathrm{fmol})$ or an $R P 51 A$ fragment from -416 to $-24(2 \mathrm{fmol})$, in the presence of $280 \mathrm{fmol}$ of pUC19 DNA and 0.18 to $1.2 \mu \mathrm{g}$ of protein extract. Panel A is a graphical representation of the elution of TCMI and $R P 51 A$ binding activities, taken from the gel shift results shown in panel B.

$\mathrm{UAS}_{\mathrm{T}}$ binding activity was assayed with the promoter fragment from pUC-Z3 (extending from -236 to +43 ), while UAS $_{\text {rpg }}$ binding activity was assayed with a fragment of rp gene RP5IA; the particular segment of RP5IA (from -416 to -24) was the same as that used originally to detect the TUF factor $(14,46)$. In Fig. 9, it can be seen that $\mathrm{UAS}_{\mathrm{T}}$ binding activity (TAF) eluted as a slightly stepped peak from 0.115 to $0.2 \mathrm{M}\left(\mathrm{NH}_{4}\right)_{2} \mathrm{SO}_{4}$ with the maximal peak binding activity centered at $0.14 \mathrm{M}$. Maximal RP5IA binding activity (TUF) eluted at $0.16 \mathrm{M}\left(\mathrm{NH}_{4}\right)_{2} \mathrm{SO}_{4}$ with the peak eluting from 0.145 to $0.215 \mathrm{M}$, in agreement with the previous published value of peak elution around $0.2 \mathrm{M}\left(\mathrm{NH}_{4}\right)_{2} \mathrm{SO}_{4}(14)$. This small but reproducible difference between the elution profiles of TAF and TUF suggested that there were indeed two distinct binding activities present in the extract, a conclusion reinforced by the finding that some protein fractions exhibited significant TCMI binding activity but no RP51A binding activity. Further, in all of these experiments the binding reactions were carried out under conditions (no $\mathrm{MgCl}_{2}$ ) that have been shown to greatly stabilize TUF-UAS ${ }_{\text {rpg }}$ complexes (46), so that even weak TUF binding to TCMI should have been discernable.

To verify that TAF and TUF binding activities were indeed different, we assayed the binding of a TCMI promoter fragment in the presence of a large molar excess of RP5IA DNA. Figure 10 shows the results of such an experiment. In the presence of a fivefold molar excess of unlabeled TCMI competitor DNA (lane 4, Fig. 10), a slight 


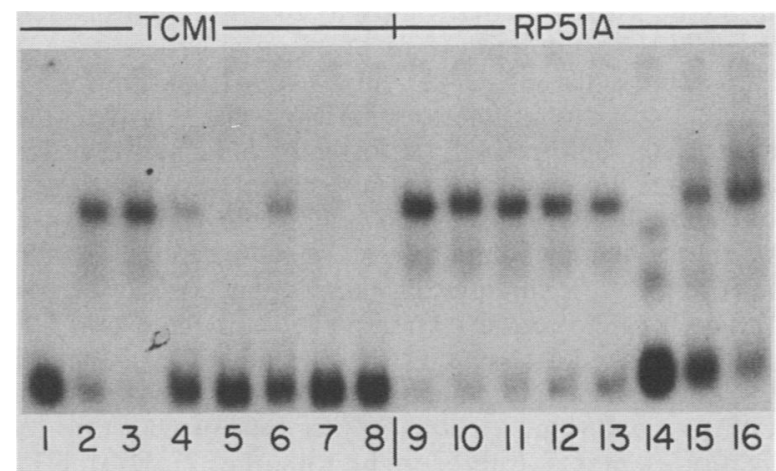

FIG. 10. Competition between $T C M I$ and $R P 5 I A$ promoter fragments for protein factors. A ${ }^{32} \mathrm{P}$-labeled $T C M I$ promoter fragment (5 fmol) was incubated with protein extract in the presence of an excess of either unlabeled TCMI or RP5IA DNA. Lanes: 1, no protein; 2, $0.25 \mu \mathrm{g}$ of protein extract (from fraction 39 shown in Fig. 9); 3, $0.5 \mu \mathrm{g}$ of extract; 4 through $8,0.5 \mu \mathrm{g}$ of extract and 5-, 10-, 10-, 50 -, and 100-fold molar excesses of unlabeled TCMI DNA, respectively; 9 through $13,0.5 \mu \mathrm{g}$ of extract and 5-, 10-, 10-, 50-, and 100 -fold molar excesses of unlabeled RP5IA DNA, respectively (note that in lanes 6 and 11 the competitor DNA was a restriction enzyme digest containing unlabeled promoter fragments as free linear molecules; all other competitor DNAs were supercoiled plasmids containing the appropriate promoter sequence). Lane 14 contained a ${ }^{32} \mathrm{P}$-labeled $R P 51 A$ promoter fragment $(5 \mathrm{fmol})$, as do lanes 15 and 16, in which the fragment was incubated with 0.25 and $0.5 \mu \mathrm{g}$ of protein extract (the two larger labeled bands in lane 14 are the result of incomplete digestion of the RP5IA plasmid used to prepare the labeled probe). All lanes contained $560 \mathrm{fmol}$ of pUC19 DNA in addition to specific competitor DNA.

reduction was noticed in the amount of labeled TCMI DNA-protein complex. At a 50- or 100-fold molar excess of TCMI competitor DNA, complex formation was abolished completely (lanes 7 and 8). However, in the presence of a 50or 100-fold excess of RP5IA competitor DNA (lanes 12 and 13), only a very slight diminution in $T C M 1$ promoter-protein complex formation was observed. The slight effect was probably due to the presence of a 50 and $100 \%$ greater amount of pUC19 carrier plasmid DNA in the 50- and 100 -fold excess samples, respectively, compared to the 5-fold-excess sample; similar slight effects have been seen in other experiments in which only pUC19 plasmid DNA was used as competitor (data not shown). In conclusion, these results together with other data presented below demonstrated that TAF and TUF are distinct rp gene trans-acting factors.

Identification of TAF by DNA-protein cross-linking. To further distinguish TAF from the TUF factor, we endeavored to identify TAF by SDS-polyacrylamide gel electrophoresis following photochemical cross-linking to radiolabeled UAS $_{\mathrm{T}}$ DNA. Cross-linking might also reveal whether more than one protein was bound to the TCMI promoter in our assays.

TAF was detected by using a photochemical cross-linking method similar to that described by Chodosh et al. (6). First, we synthesized single-stranded DNA oligonucleotides corresponding to the (noncoding strand) promoter sequence of either TCMI (containing UAS $\mathrm{T}_{\mathrm{T}}$ ) or rp gene $L 25$ (containing $\left.\mathrm{UAS}_{\mathrm{rpg}}\right)$. The oligomers were each 46 bases in size, the 3 '-most 15 bases being complementary to the M13 sequencing primer (see Materials and Methods). Following annealing, the M13 primer was extended across the promoter sequences with DNA polymerase in the presence of 5- bromo- 2 '-deoxy(UTP) (5BrdU) and $\left[\alpha-{ }^{32} \mathrm{P}\right] \mathrm{dATP}$, thereby synthesizing the second strand. 5BrdU substitutes for thymidine and increases the efficiency of photochemical crosslinking to proteins. After synthesis, the double-stranded oligonucleotides were incubated with an extract containing both TAF and TUF binding activities. Half of the incubation mixtures was analyzed by nondenaturing gel electrophoresis to confirm protein binding to the 5BrdU-substituted DNA; $5 B r d U$ substitution did not affect binding efficiency (data not shown). The other half of each mixture was irradiated with a UV lamp $\left(\lambda_{\max }, 300 \mathrm{~nm}\right)$ to cross-link bound protein to the DNA. After irradiation, the samples were treated with DNase I to remove nucleotides not cross-linked to protein and the mixture was subjected to SDS-polyacrylamide gel electrophoresis. Proteins that had been bound to the DNA were revealed by the remnant of cross-linked radioactively labeled DNA.

Figure 11A shows the nondenaturing gel in which could be seen that both $5 \mathrm{BrdU}$-substituted oligonucleotides, $\mathrm{UAS}_{\mathrm{T}^{-}}$ $\mathrm{UV}$ and $U A S_{\mathrm{rpg}}-\mathrm{UV}$, were shifted in mobility by binding to proteins, presumably TAF and TUF, respectively (lanes 2 , 3,7 , and 8). Binding was specific for each oligomer. Protein binding to the labeled $\mathrm{UAS}_{\mathrm{T}}-\mathrm{UV}$ oligomer was abolished completely by a 1,500 -fold molar excess of unlabeled $\mathrm{UAS}_{\mathrm{T}^{-}}$ UV (lane 4) while a 1,500-fold molar excess of UAS ${ }_{r p g}-U V$ had no effect on binding to labeled $U_{A S}$-UV (lane 5). The analogous situation held for the labeled $\mathrm{UAS}_{\mathrm{rpg}}-\mathrm{UV}$ probe; an excess of unlabeled UAS ${ }_{\mathrm{rpg}}-\mathrm{UV}$ DNA abolished protein binding to labeled $U_{A S} S_{r p g}-U V$ (lane 10), while the presence of excess $U_{A S}-U V$ had no effect (lane 9). The two proteinDNA complexes also differed slightly in electrophoretic mobility; the complex containing $\mathrm{UAS}_{\mathrm{T}}$-UV had a greater mobility than the complex containing $\mathrm{UAS}_{\mathrm{rpg}}-\mathrm{UV}$ (see arrows in Fig. 11A). Since the DNA components of both complexes were exactly the same size, this difference in mobility suggested the presence of different proteins in the two complexes.

Figure 11B shows an autoradiogram of the SDS-polyacrylamide gel in which, following photochemical cross-linking and DNase digestion, the same samples as those in Fig. 11A were subjected to electrophoresis. Lane 3, which contained ${ }^{32}$ P-labeled UAS T $_{\mathrm{T}}$-UV and unlabeled pUC19 plasmid DNA as nonspecific competitor, revealed two labeled proteins with relative molecular masses of 82 and $147 \mathrm{kDa}$. The presence of these two proteins was dependent upon prior UV irradiation (see lane 2, no UV). Both polypeptides were absent when unlabeled $\mathrm{UAS}_{\mathrm{T}}-\mathrm{UV}$ was used as competitor (lane 4) but unlabeled $U A S_{r p g}-U V$ competitor (lane 5) had no effect on their appearance (there was actually a slight and reproducible diminution in the 82-kDa species; see Discussion). Similarly lane 8 , which contained ${ }^{32} \mathrm{P}$-labeled $\mathrm{UAS}_{\mathrm{rpg}^{-}}$ UV and pUC19, revealed proteins with relative molecular masses of 82, 102, and $126 \mathrm{kDa}$. Appearance of all three of these proteins was prevented by excess unlabeled $\mathrm{UAS}_{\mathrm{rpg}}{ }^{-}$ UV (lane 10) but not by excess $\mathrm{UAS}_{\mathrm{T}}$-UV (lane 9) DNA.

The TUF factor that binds to $\mathrm{UAS}_{\mathrm{rpg}}$ has been reported to migrate in SDS-polyacrylamide gels with a mobility corresponding to a molecular mass of 120 to $150 \mathrm{kDa}(15,41)$. It was not possible to conclude definitively which (if any) of the three polypeptides seen in lanes 8 and 9 were TUF, although we suspect that the $126-\mathrm{kDa}$ polypeptide is indeed that factor. Nonetheless, the finding of at least one polypeptide (the $147-\mathrm{kDa}$ species) that bound specifically to UAS $\mathrm{US}_{\mathrm{T}}$ and that had a size different from those binding to UAS ${ }_{r p g}$ 


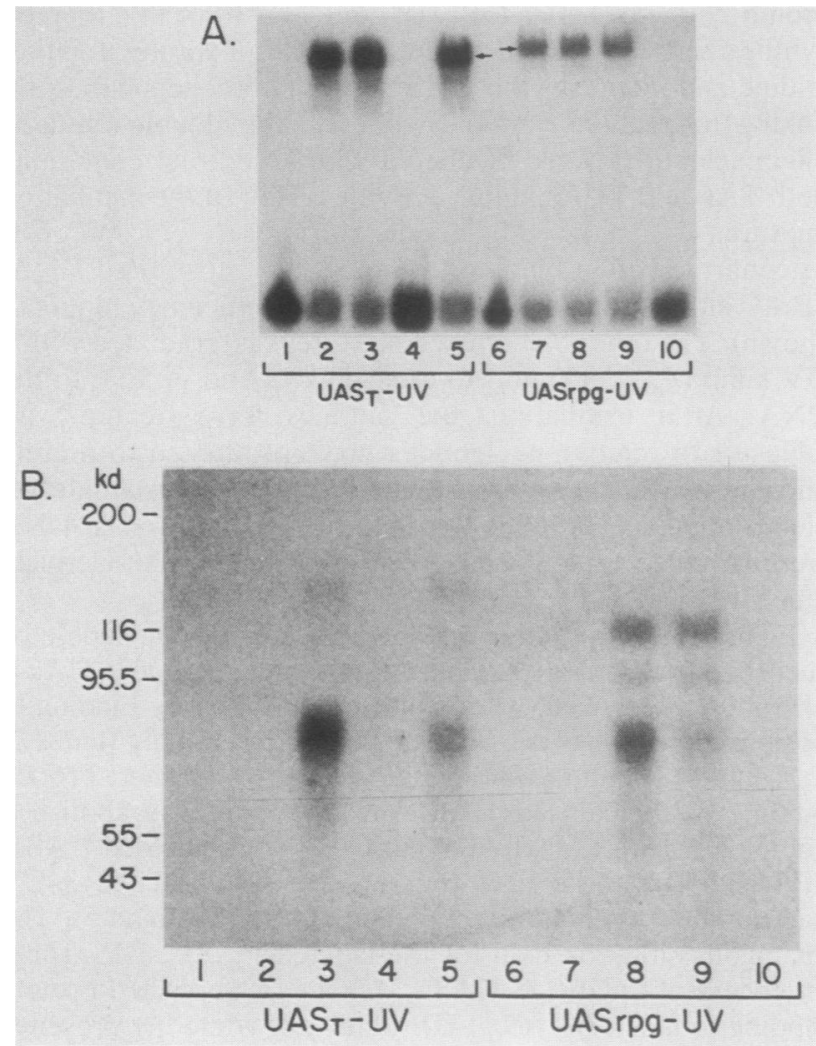

FIG. 11. Photochemical cross-linking of UAS $\mathrm{U}_{\mathrm{T}}$ and TAF. (A) Autoradiogram of a nondenaturing gel analysis of DNA-protein complexes formed with the $5 \mathrm{BrU}$-substituted double-stranded oligonucleotides $U A S_{T}-U V$ and $U A S_{r p g}-U V$, containing one copy of the cis-acting sequence $\mathrm{UAS}_{\mathrm{T}}$ or $\mathrm{UAS}_{\mathrm{rpg}}$, respectively. DNAprotein complexes were formed in the presence of $5 \mathrm{fmol}$ of labeled oligonucleotide, $7,700 \mathrm{fmol}$ of specific competitor DNA ( $200 \mathrm{ng}$ of appropriate oligonucleotide; see Materials and Methods) and 1,900 fmol $(4 \mu \mathrm{g})$ of nonspecific double-stranded pUC119 DNA. The source of DNA-binding proteins was a heparin-agarose column fraction (Fig. 9) that contained both $\mathrm{UAS}_{\mathrm{T}}$ and $\mathrm{UAS}_{\mathrm{rpg}}$ binding activity. Lanes 1 through 5 contained labeled $U A S_{T}-U V$ oligonucleotide, and lanes 6 through 10 contained labeled $U_{A S} S_{\mathrm{rpg}}-U V$ oligonucleotide. Protein extract was absent in the samples loaded in lanes 1 and 6; lanes 2, 3, 7, and 8 contained only nonspecific pUC119 DNA; lanes 4 and 9 contained specific $U_{A S} S_{T}-U V$ competitor DNA, and lanes 5 and 10 contained specific $U_{A S_{\text {rpg }}}$-UV DNA. Each of the same samples analyzed in the gel shown in this panel was irradiated with 300-nm UV light to cross-link bound proteins. The irradiated samples were treated with DNase I to remove noncross-linked DNA, and the samples were then subjected to SDS-polyacrylamide gel electrophoresis. (B) Autoradiogram of the SDS gel shown in panel A; lanes are the same as in panel A. Note that the samples applied to lanes 2 and 7 were not treated with UV light. kd, Kilodaltons.

reinforced the conclusion that TAF and TUF were distinct transcription factors.

\section{DISCUSSION}

We have demonstrated that the sequence TCGTTTTGTA CGTTTTTCA, designated $\mathrm{UAS}_{\mathrm{T}}$, is an upstream transcriptional activation element of yeast rp gene TCMI, and we have provided evidence that TAF, a protein which bound to $\mathrm{UAS}_{\mathrm{T}}$ in vitro, is a coparticipant in activation. Experiments are also described indicating that TAF is a factor distinct from TUF, a protein that binds to the principal cis-acting element $\mathrm{UAS}_{\mathrm{rpg}}$ common to most other rp genes.

The importance of $\mathrm{UAS}_{\mathrm{T}}$ in $T C M I$ transcription was revealed by promoter deletions showing that removal of part or all of $\mathrm{UAS}_{\mathrm{T}}$ reduced transcription by at least one order of magnitude. Conversely, in promoter constructs from which $\mathrm{UAS}_{\mathrm{T}}$ and adjoining nucleotides were absent, reinsertion of $\mathrm{UAS}_{\mathrm{T}}$ alone was sufficient to restore transcription (8 to $38 \%$ of maximum). The finding that the sequence restored significant levels of expression when placed upstream of a $C Y C l$ gene that lacked its own UAS was added evidence that $\mathrm{UAS}_{\mathrm{T}}$ is a transcriptional activator. Also, $\mathrm{UAS}_{\mathrm{T}}$ functioned in either orientation, a common property of transcriptional activation elements. Interestingly, for either $T C M I$ or $C Y C I$, $\mathrm{UAS}_{\mathrm{T}}$ promoted reproducibly greater expression when situated in the orientation opposite to its natural occurrence. Similarly higher activity associated with reversed orientation was found for the $\mathrm{UAS}_{\mathrm{rpg}}$ element derived from rp gene $L 25$ (50). Finally, the role of $U_{A S}$ in expression of TCMI was confirmed by assaying the transcriptional potency of altered $\mathrm{UAS}_{\mathrm{T}}$ oligomers. Either omission of the $5^{\prime}$-terminal $\mathrm{T}$ or substitution of the $T$ in position 15 by a $G$ rendered $U_{A S} S_{T}$ a considerably less effective transcriptional activator.

The conclusion that TAF is involved in TCMI transcription was based on the finding that DNA fragments containing $\mathrm{UAS}_{\mathrm{T}}$ formed specific DNA-protein complexes after incubation in a cell-free extract; DNA fragments lacking $\mathrm{UAS}_{\mathrm{T}}$ did not bind specifically to any protein. Footprinting experiments revealed that TAF protected $\mathrm{UAS}_{\mathrm{T}}$ from cleavage by either DNase I or MPE. Finally, two altered versions of $\mathrm{UAS}_{\mathrm{T}}$ that were less effective at promoting transcription in vivo also were less effective in binding to TAF in vitro.

Although TAF bound less efficiently to transcriptionally impaired UAS T $_{\mathrm{T}}$ sequences, we did not find an exact quantitative correlation between binding and transcriptional activity. Within experimental error, TAF bound equally well to either of the two mutant $\mathrm{UAS}_{\mathrm{T}} \mathrm{s}, \mathrm{UAS}_{\mathrm{T}} \Delta \mathrm{T}$ and $\mathrm{UAS}_{\mathrm{T}} \mathrm{G}$. At a 50-fold molar excess, each mutant sequence was about $30 \%$ as efficient as $\mathrm{UAS}_{\mathrm{T}}$ in competing with a labeled $\left(\mathrm{UAS}_{\mathrm{T}}\right)$ probe for binding to TAF. At 100-fold excess, competition efficiency was 55 to $88 \%$ that of $\mathrm{UAS}_{\mathrm{T}}$. However, in vivo $\mathrm{UAS}_{\mathrm{T}} \Delta \mathrm{T}$ showed a greater diminution in transcriptional activity, supporting expression at only $10 \%$ the level of $\mathrm{UAS}_{\mathrm{T}}$, compared with $30 \%$ exhibited by $\mathrm{UAS}_{\mathrm{T}} \mathrm{G}$. Further purification of TAF and in-depth kinetic studies of its binding to various $\mathrm{UAS}_{\mathrm{T}}$ sequences will be necessary to clarify this discrepancy.

The TAF binding site UAS ${ }_{\mathrm{T}}$ has several features that lead to speculation about its interaction with transcription factors. If its $5^{\prime}$-most nucleotide is ignored, the sequence of $\mathrm{UAS}_{\mathrm{T}}$ can be broken down into two nearly perfect repeats: (T)CGTTTTGTACGTTTTTCA $\rightarrow$ CGTTTTGTA and CGT TTTTCA, with the average sequence being CGTT $\mathrm{TT}^{\mathrm{T}} / \mathrm{G}_{\mathrm{G}} \mathrm{C} / \mathrm{T}$. The two repeats are each $9 \mathrm{bp}$ and, since there are no nucleotide residues between each repeat, both 9-base segments would lie almost on the same face of the DNA helix, assuming standard B-form DNA. This disposition suggests that two molecules of TAF might bind to $\mathrm{UAS}_{\mathrm{T}}$, perhaps cooperatively, one molecule to each repeated sequence. A cooperative interaction between protein monomers on $\mathrm{UAS}_{\mathrm{T}}$ would require slight twisting of the two repeat sequences relative to one another, as they are $1 \mathrm{bp}$ from being exactly on the same face of the helix. An argument against such an interaction is that $T$ stretches such as those in $\mathrm{UAS}_{\mathrm{T}}$ are relatively rigid (5). An argument in favor of cooperative interaction can be made from the 


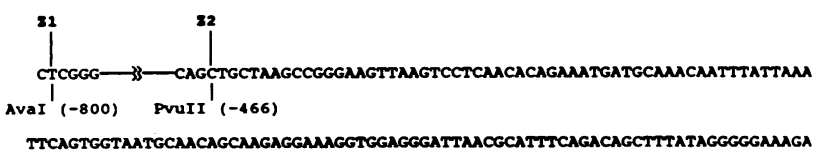

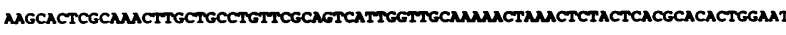

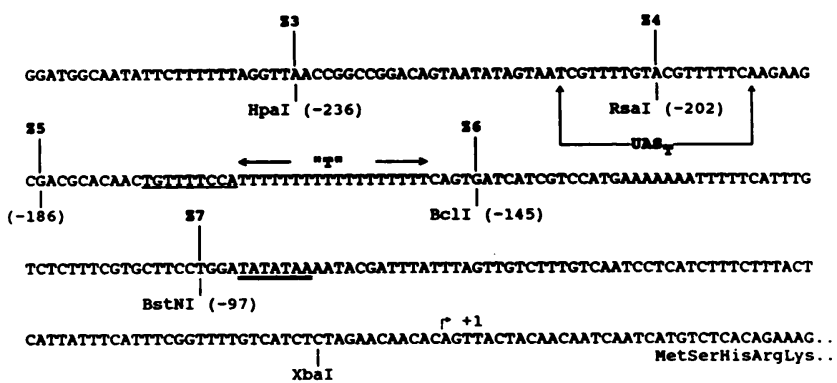

FIG. 12. DNA sequence of $T C M I$ promoter region. Vertical bars designate positions of deletion endpoints described in Fig. 1. The box with arrows surrounding the $R s a I$ restriction enzyme site at -202 delineates the 19-bp activation region of TCMI, UAS T $_{\mathrm{T}}$ The underlined sequence indicates a segment with homology to the two halves of $\mathrm{UAS}_{\mathrm{T}}$. "T", Prominent T-rich region; such regions are characteristic of yeast promoters, usually found between UAS elements and the TATA homology (double underlined) and necessary for maximal transcription (42). +1, Transcription start site determined by primer extension (M. Underwood and H. Fried, unpublished data).

observation that a single repeat sequence was insufficient to promote transcription; a deletion leaving only the second repeat all but obliterated transcription (pTCM-Z4 in Fig. 1; see also Fig. 12), while placement of the first repeat at -145 (Fig. 1, pTCM-Z9) likewise failed to sustain transcription. Yet, while it is interesting to speculate that $\mathrm{UAS}_{\mathrm{T}}$ consists of two adjacent binding sites for the same protein, we can not overlook the fact that the $5^{\prime}$ terminal residue $(T)$ of $U_{A S}$ is also required for maximal transcription; this residue does not occur in the second repeated sequence, suggesting that $\mathrm{UAS}_{\mathrm{T}}$ may not consist of tandemly duplicated binding sites.

Finally, we return to the original question that prompted this study. Ribosome synthesis in eucaryotes requires the coordinated accumulation of over 70 different proteins. To manage this system, it has been widely assumed that cells possess a uniform mechanism to control expression of rp genes. Indeed, transcription of many yeast rp genes involves common cis- and trans-acting elements (25). The transacting factor is a protein called TUF which binds to the cis-acting DNA sequence $\mathrm{UAS}_{\mathrm{rpg}}$, some version of which resides $5^{\prime}$ of at least 19 yeast rp genes. Deletion of TUF binding sites leads to near total loss of transcription.

In the original comparisons that suggested the existence of a common sequence, no readily apparent $\mathrm{UAS}_{\mathrm{rpg}}$ homolog was recognized adjacent to either TCMI or rp gene $S 33(24$, 43). Lack of $U A S_{\text {rpg }}$ seemed counter to the expectation of a uniform mechanism for yeast rp gene transcription. We have confirmed the absence of a UAS ${ }_{\text {rpg }}$ sequence in TCM1 by finding that its principal cis-acting element, $\mathrm{UAS}_{\mathrm{T}}$, bears no resemblance to the $\mathrm{UAS}_{\mathrm{rpg}}$ consensus aPyCPyPutPuCaPyPy $/$ a (51). Furthermore, the lack of a recognizable UAS $_{\text {rpg }}$ homology in TCMI was deduced from sequence data encompassing only 236 bp upstream of TCMI; we have extended the sequence to -465 bp (Fig. 12) but find no obvious $\mathrm{UAS}_{\mathrm{rpg}}$-like element, and in any case, deletion of all sequence upstream of -236 had no measurable effect on TCMI transcription. Thus, there is no indication of a
$\mathrm{UAS}_{\mathrm{rpg}}$-TUF interaction in expression of $T C M 1$. $\mathrm{UAS}_{\mathrm{T}}$ may not be unique to $T C M 1$; while comparison of $\mathrm{UAS}_{\mathrm{T}}$ to sequences in nucleic acid databases failed to detect any $5^{\prime}$ gene sequences with fewer than 3 mismatches, Southern blot hybridization between a radiolabeled $\mathrm{UAS}_{\mathrm{T}}$ oligomer and yeast genomic DNA revealed 5 to 10 restriction fragments under conditions allowing for $15 \%$ mismatch (data not shown).

Paralleling the dissimilarity between the two rp gene UASs, the $\mathrm{UAS}_{\mathrm{T}}$ binding protein TAF was found to be distinct from TUF, the $\mathrm{UAS}_{\mathrm{rpg}}$ binding factor. TCM1specific binding activity eluted from a heparin-agarose column ahead of UAS $_{\text {rpg }}$ binding activity. Furthermore, neither DNA sequence competed with the other for binding to protein in such column fractions. Finally, photochemical cross-linking experiments revealed $T C M I$ binding proteins with mobilities corresponding to 147 and $82 \mathrm{kDa}$. When the same technique was applied to a $U_{A S}$ rpg DNA-protein complex, proteins of 126,102 , and $82 \mathrm{kDa}$ were observed. The occurrence of at least one different protein in the UAS DNA-protein complex than in the $\mathrm{UAS}_{\mathrm{rpg}}$ complex strongly suggested that TAF and TUF are different factors. As discussed below, we ascribe the designation TAF to the 147-kDa protein.

It could be argued that TAF and TUF are in fact identical and that the 82-, 102-, and 126-kDa polypeptides that bound to $\mathrm{UAS}_{\mathrm{rpg}}$ were simply remaining proteolytic fragments of the same $147-\mathrm{kDa}$ protein that bound to $\mathrm{UAS}_{\mathrm{T}}$, especially since an $82-\mathrm{kDa}$ protein was also found associated with $\mathrm{UAS}_{\mathrm{T}}$. This possibility was unlikely because the same sample of protein extract was used to form DNA-protein complexes with both $\mathrm{UAS}_{\mathrm{T}}$ and $\mathrm{UAS}_{\mathrm{rpg}}$ probes; therefore, an identical spectrum of polypeptides should have been revealed with either probe, were TAF and TUF the same factor. Furthermore, the $126-\mathrm{kDa}$ polypeptide had very nearly the same gel mobility as a known value for TUF (41), supporting the conclusion that TAF and TUF are different factors. Finally, results from the gel shift assay suggest that different constellations of proteins were bound to $\mathrm{UAS}_{\mathbf{T}}$ and UAS $_{\text {rpg. The }}$ UAS ${ }_{\text {rpg }}$ DNA-protein complex migrated slightly slower than the $\mathrm{UAS}_{\mathrm{T}}$ DNA-protein complex in nondenaturing gels, even though the DNA components of each complex were identical in size. Reduced mobility could be explained by the fact that the minimum combined molecular mass of the polypeptides detected by cross-linking to $\mathrm{UAS}_{\mathrm{rpg}}$ was $310 \mathrm{kDa}$, while that for $\mathrm{UAS}_{\mathrm{T}}$ was $229 \mathrm{kDa}$.

The TUF factor has been reported to have a mobility corresponding to 120 to $150 \mathrm{kDa}$ in denaturing polyacrylamide gels $(15,41)$, although on the basis of sequence of the gene believed to encode TUF, the protein has an actual molecular mass of $92.5 \mathrm{kDa}(41)$. We suspect that the 126-kDa protein detected in our cross-linking experiments is the TUF factor, although this hypothesis will require direct verification. Since there is yet no report of additional proteins that bind to the UAS rpg $_{\text {sequence, we were surprised to }}$ find two other polypeptides cross-linked to UAS ${ }_{\text {rpg }}$, a 102 $\mathrm{kDa}$ and an 82-kDa species. Although one or both of the other two proteins could have been proteolytic products derived from the $126-\mathrm{kDa}$ polypeptide, we believe that at least the $82-\mathrm{kDa}$ species is a heretofore unidentified transcription factor, since an $82-\mathrm{kDa}$ polypeptide also crosslinked to $\mathrm{UAS}_{\mathrm{T}}$. The 82-kDa proteins were probably one and the same because when UAS $_{\text {rpg }}$ was included as a competitor, we consistently observed a slight diminution in the abundance of the $82-\mathrm{kDa}$ species cross-linked to $\mathrm{UAS}_{\mathrm{T}}$ but the competitor did not affect the amount of the $147-\mathrm{kDa}$ 
species bound; likewise, excess $\mathrm{UAS}_{\mathrm{T}}$ slightly diminished binding of the $82-\mathrm{kDa}$ species to $\mathrm{UAS}_{\mathrm{rpg}}$ without affecting binding of the other protein(s) (Fig. 11B, lanes 5 and 10). Thus, both DNA sequences competed for the same protein. We would point out, however, that competition was far less than complete despite the presence of a 1,500-fold molar excess of competitor, suggesting that the $82-\mathrm{kDa}$ protein was substantially more abundant in our extracts compared with the amount of input DNA probe.

This latter point suggests that binding of the $82-\mathrm{kDa}$ protein to $\mathrm{UAS}_{\mathrm{T}}$ and $\mathrm{UAS}_{\mathrm{rpg}}$ requires prior (or simultaneous) binding of TAF or TUF. If the $82-\mathrm{kDa}$ species could have bound independently of the other two factors, then for example, the presence of a 1,500-fold excess of unlabeled UAS $_{\mathrm{T}}$ should not have prevented the $82-\mathrm{kDa}$ protein from cross-linking to the labeled $\mathrm{UAS}_{\mathrm{T}}$ DNA, since the $82-\mathrm{kDa}$ protein was in excess over the DNA. The fact that the 82-kDa protein totally failed to cross-link to labeled $\mathrm{UAS}_{\mathrm{T}}$ in the presence of excess unlabeled $U_{A S}$ suggested that the excess competitor prevented TAF from binding, which, in turn, eliminated binding of the $82-\mathrm{kDa}$ protein. The $82-\mathrm{kDa}$ protein must also have been in contact with DNA to be cross-linked. However, this binding is difficult to reconcile with the fact that highly purified TUF factor produced the same UAS $_{\text {rpg }}$ DNA footprint as that seen with a crude extract (15), suggesting that no other protein but TUF

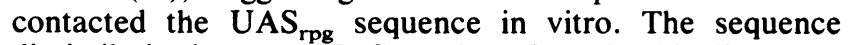
dissimilarity between $\mathrm{UAS}_{\mathrm{T}}$ and $\mathrm{UAS}_{\mathrm{rpg}}$ also highlights the question of how the same protein might bind to the two elements.

In summary, we propose that transcription of yeast $\mathrm{rp}$ gene $T C M I$ is based on a set of transcription components different in part from that common to most other rp genes. Curious as this situation may seem, there is no a priori reason that all such genes should rely on the same mechanism of expression. As has been demonstrated, the critical determinant appears to be the quantity of $\mathrm{rp} \operatorname{mRNAs}(1,31$, 35). An equivalent amount of mRNA for each protein seems to ensure an equivalent rate of synthesis of each polypeptide, a desirable outcome given the equimolar presence of each protein in the ribosome. Thus, it need not matter which cis- and trans-acting elements constitute a particular rp gene transcription apparatus, providing each apparatus is similarly efficient.

Disparity between the activation elements of $T C M 1$ and the bulk of other yeast rp genes is perhaps disquieting when considering regulation of rp gene transcription. For example, the rate of synthesis of rp is stimulated by a factor of 3 to 5 accompanying a shift from a poor carbon source to glucose (17). The increase is due to elevated rp gene transcription (7) and, at least for rp gene $L 25$, the effect was shown to be mediated by a UAS ${ }_{\text {rpg }}$ element (13). Unfortunately, data describing the effect of carbon source shift on either synthesis of $\mathrm{L} 3$ (the product of TCMI) or transcription of TCMI are not available $(7,17)$. Nonetheless, it seems reasonable to assume that TCMI gene expression responds in a similar fashion and it remains to be seen whether $\mathrm{UAS}_{\mathrm{T}}$ does for TCM1 what $\mathrm{UAS}_{\mathrm{rpg}}$ does for its other ribosomal gene colleagues. If so, are the corresponding protein factors TUF and TAF independently responsive to environmental conditions, or might each factor be subservient to others that control interaction of TUF and TAF with their respective promoters during environmental alterations? As mentioned above, the 82-kDa polypeptide we found cross-linked to both $\mathrm{UAS}_{\mathrm{T}}$ and $\mathrm{UAS}_{\mathrm{rpg}}$ may be a candidate for a factor that coordinately regulates $\mathrm{rp}$ gene transcription.

\section{ACKNOWLEDGMENTS}

We thank Malcolm Casadaban, Leonard Guarente, Michael Rosbash, David Botstein, Fred Sherman, and Beverly Errede for strains and plasmids. We are grateful to Mary Ellen Jones and the members of her laboratory for assistance with ODCase enzyme assays, to Ben Van Houten and Intisar Husain for the gift of MPE and guidance in footprinting experiments, and to Chi-Bom Chae for advice on photochemical cross-linking.

This research was initiated with grant PCM-8215576 from the National Science Foundation and continued by Public Health Service grant GM37117 from the National Institutes of Health.

\section{LITERATURE CITED}

1. Abovich, N., L. Gritz, L. Tung, and M. Rosbash. 1985. Effect of rp51 gene dosage alterations on ribosome synthesis in Saccharomyces cerevisiae. Mol. Cell. Biol. 5:3429-3435.

2. Abovich, N., and M. Rosbash. 1984. Two genes for ribosomal protein 51 of Saccharomyces cerevisiae complement and contribute to the ribosomes. Mol. Cell. Biol. 4:1871-1879.

3. Altmann, M., C. Handschin, and H. Trachsel. 1987. mRNA cap-binding protein: cloning of the gene encoding protein synthesis initiation factor eIF-4E from Saccharomyces cerevisiae. Mol. Cell. Biol. 7:998-1003.

4. Bradford, M. M. 1976. A rapid and sensitive method for the quantitation of microgram quantities of protein utilizing the principal of protein-dye binding. Anal. Biochem. 72:248-254.

5. Burkhoff, A. M., and T. D. Tullius. 1987. The unusual conformation adopted by the adenine tracts of kinetoplast DNA. Cell 48:935-943.

6. Chodosh, L. A., R. W. Carthew, and P. A. Sharp. 1986. A single polypeptide possesses the binding and transcription activities of the adenovirus major late transcription factor. Mol. Cell. Biol. 6:4723-4733.

7. Donovan, D. M., and N. J. Pearson. 1986. Transcriptional regulation of ribosomal proteins during a nutritional upshift in Saccharomyces cerevisiae. Mol. Cell. Biol. 6:2429-2435.

8. Fried, H. M., H. G. Nam, S. Loechel, and J. Teem. 1985. Characterization of yeast strains with conditionally expressed variants of ribosomal protein genes $t \mathrm{cml}$ and $c y h 2$. Mol. Cell. Biol. 5:99-108.

9. Garner, M. M., and A. Revzin. 1981. A gel electrophoresis method for quantifying the binding of proteins to specific DNA regions: application to components of the Escherichia coli lactose operon regulatory system. Nucleic Acids Res. 9:30483061.

10. Gerbaud, C., and M. Guerinéau. 1980. $2 \mu \mathrm{m}$ plasmid copy number in different yeast strains and repartition of endogenous and $2 \mu \mathrm{m}$ chimeric plasmids in transformed strains. Curr. Genet. 1:219-228.

11. Gorenstein, C., and J. R. Warner. 1976. Coordinate regulation of the synthesis of eukaryotic ribosomal proteins. Proc. Natl. Acad. Sci. USA 73:1547-1551.

12. Guarente, L., and M. Ptashne. 1981. Fusion of Escherichia coli lacZ to the cytochrome $c$ gene of Saccharomyces cerevisiae. Proc. Natl. Acad. Sci. USA 78:2199-2203.

13. Herruer, M. H., W. H. Mager, L. P. Woudt, R. T. M. Nieuwint, G. M. Wassenaar, P. Groeneveld, and R. J. Planta. 1987. Transcriptional control of yeast ribosomal protein synthesis during carbon-source upshift. Nucleic Acids Res. 15:10133-10144.

14. Huet, J., P. Cottrelle, M. Cool, M.-L. Vignais, D. Thiele, C. Marck, J.-M. Buhler, A. Sentenac, and P. Fromageot. 1985. A general upstream binding factor for genes of the yeast translational apparatus. EMBO J. 4:3539-3547.

15. Huet, J., and A. Sentenac. 1987. TUF, the yeast DNA-binding factor specific for UAS $_{\text {rpg }}$ upstream activating sequences: identification of the protein and its DNA-binding domain. Proc. Natl. Acad. Sci. USA 84:3648-3652.

16. Husain, I., G. B. Sancar, S. R. Holbrook, and A. Sancar. 1987. Mechanism of damage recognition by Escherichia coli DNA photolyase. J. Biol. Chem. 262:13188-13197.

17. Kief, D. R., and J. R. Warner. 1981. Coordinate control of synthesis of ribosomal ribonucleic acid and ribosomal proteins during nutritional shift-up in Saccharomyces cerevisiae. Mol. 
Cell. Biol. 1:1007-1015.

18. Kim, C.-H., and J. R. Warner. 1983. Mild temperature shock alters the transcription of a discrete class of Saccharomyces cerevisiae genes. Mol. Cell. Biol. 3:457-465.

19. Kim, C. H., and J. R. Warner. 1983. Messenger RNA for ribosomal proteins in yeast. J. Mol. Biol. 165:79-89.

20. Kosiba, B. E., B. Errede, T. S. Cardillo, and F. Sherman. 1982. Mutants of yeast overproducing iso-2 cytochrome $c$. Recent Adv. Yeast Mol. Biol. 1:156-172.

21. Kraig, E., J. E. Haber, and M. Rosbash. 1982. Sporulation and rna2 lower ribosomal protein mRNA levels by different mechanisms in Saccharomyces cerevisiae. Mol. Cell. Biol. 2:1194 1204.

22. Laemmli, U. K. 1970. Cleavage of structural proteins during the assembly of the head of bacteriophage T4. Nature (London) 227:680-685.

23. Larkin, J. C., J. R. Thompson, and J. L. Woolford, Jr. 1987. Structure and expression of the Saccharomyces cerevisiae CRY1 gene: a highly conserved ribosomal protein gene. Mol. Cell. Biol. 7:1764-1775.

24. Leer, R. J., M. M. C. Van Raamsdonk-Duin, W. H. Mager, and R. J. Planta. 1985. Conserved sequences upstream of yeast ribosomal protein genes. Curr. Genet. 9:273-277.

25. Mager, W. H. 1988. Control of ribosomal protein gene expression. Biochim. Biophys. Acta 949:1-15.

26. Mann, C., J.-M. Buhler, I. Treich, and A. Sentenac. 1987. $R P C 40$, a unique gene for a subunit shared between yeast RNA polymerase $A$ and $C$. Cell 48:627-637.

27. Maxam, A. M., and W. Gilbert. 1980. Sequencing end-labeled DNA with base-specific chemical cleavages. Methods Enzymol. 65:499-560.

28. Messing, J. 1983. New M13 vectors for cloning. Methods Enzymol. 101:20-78.

29. Miller, J. H. 1972. Experiments in molecular genetics, p. 352355. Cold Spring Harbor Laboratory, Cold Spring Harbor, N.Y.

30. Molenaar, C. M. T., L. P. Woundt, A. E. M. Jansen, W. H. Mager, R. J. Planta, D. M. Donovan, and N. J. Pearson. 1984. Structure and organization of two linked ribosomal protein genes in yeast. Nucleic Acids Res. 12:7345-7358.

31. Nam, H. G., and H. M. Fried. 1986. Effects of progressive depletion of $t \mathrm{cml}$ or cyh2 mRNA on Saccharomyces cerevisiae ribosomal protein accumulation. Mol. Cell. Biol. 6:1535-1544.

32. Pearson, N. J., and J. Haber. 1980. Changes in the regulation of ribosomal protein synthesis during vegetative growth and sporulation of Saccharomyces cerevisiae. J. Bacteriol. 143:14111420.

33. Planta, R. J., W. H. Mager, R. J. Leer, L. P. Woudt, H. A. Raue, and T. T. A. L. El-Baradi. 1986. Structure and expression of ribosomal protein genes in yeast, p. 699-718. In B. Hardesty, and G. Kramer, (ed.), Structure, function and genetics of ribosomes. Springer-Verlag, New York.

34. Prabhakararao, K., and M. E. Jones. 1975. Radioassay of orotic acid phosphoribosyltransferase and orotidylate decarboxylase utilizing a high-voltage paper electrophoresis technique or an improved ${ }^{14} \mathrm{CO}_{2}$-release method. J. Biol. Chem. 69:451-467.

35. Rotenberg, M. O., M. Moritz, and J. L. Woolford. 1988. Depletion of Saccharomyces cerevisiae ribosomal protein L16 causes a decrease in 605 ribosomal subunits and formation of half-mer polyribosomes. Genes Dev. 2:160-172.
36. Rotenberg, M. O., and J. L. Woolford, Jr. 1986. Tripartite upstream promoter element essential for expression of Saccharomyces cerevisiae ribosomal protein genes. Mol. Cell. Biol. 6: $674-687$.

37. Ruet, A., S. Camier, W. Smagowicz, A. Sentenac, and $\mathbf{P}$. Fromageot. 1984. Isolation of a class $C$ transcription factor which forms a stable complex with tRNA genes. EMBO J. 3: 343-350.

38. Sanger, F., S. Nicklen, and A. R. Coulson. 1977. DNA sequencing with chain-terminating inhibitors. Proc. Natl. Acad. Sci. USA 74:5463-5467.

39. Schleif, R. 1988. DNA looping. Science 240:127-128.

40. Schwindinger, W. F., and J. R. Warner. 1987. Transcriptional elements of the yeast ribosomal protein gene $\mathrm{CYH2}$. J. Biol. Chem. 262:5690-5695.

41. Shore, D., and K. Nasmyth. 1987. Purification and cloning of a DNA binding protein from yeast that binds to both silencer and activator elements. Cell 51:721-732.

42. Struhl, K. 1987. Promoters, activator proteins, and the mechanism of transcriptional initiation in yeast. Cell 49:295-297.

43. Teem, J. L., N. Abovich, N. F. Kaufer, W. F. Schwindinger, J. R. Warner, A. Levy, J. Woolford, R. J. Leer, M. M. C. van Raamsdonk-Duin, W. H. Mager, R. J. Planta, L. Shultz, J. D. Friesen, H. M. Fried, and M. Rosbash. 1984. A comparison of yeast ribosomal protein gene DNA sequences. Nucleic Acids Res. 12:8295-8312.

44. Teem, J. L., and M. Rosbash. 1983. Expression of a $\beta$-galactosidase gene containing a ribosomal protein 51 intron is sensitive to the rna2 mutation of yeast. Proc. Natl. Acad. Sci. USA 80: 4403-4407.

45. Van Dyke, M. W., and P. B. Dervan. 1983. MethidiumpropylEDTA-Fe(II) and DNase I footprinting report different small molecule binding site sizes on DNA. Nucleic Acids Res. 11: 5555-5567.

46. Vignais, M.-L., L. Woudt, G. M. Wassenaar, W. M. Mager, A. Sentenac, and R. J. Planta. 1987. Specific binding of TUF factor to upstream activation sites of yeast ribosomal protein genes. EMBO J. 6:1451-1457.

47. Warner, J. R. 1982. The yeast ribosome: structure, function, and synthesis, p. 529-560. In J. N. Strathern, E. W. Jones, and J. R. Broach (ed.), The molecular biology of the yeast Saccharomyces. Cold Spring Harbor Laboratory, Cold Spring Harbor, N.Y.

48. Warner, J. R., and C. Gorenstein. 1978. Yeast has a true stringent response. Nature (London) 275:338-339.

49. Warner, J. R., G. Mitra, W. F. Schwindinger, M. Studeny, and H. M. Fried. 1985. Saccharomyces cerevisiae coordinates accumulation of yeast ribosomal proteins by modulating mRNA splicing, translational initiation, and protein turnover. Mol. Cell. Biol. 5:1512-1521.

50. Woudt, L. P., W. M. Mager, R. T. M. Nieuwint, G. M. Wassenaar, A. C. van der Kuyl, J. J. Murre, M. F. M. Hoekman, P. G. M. Brockhoff, and R. J. Planta. 1987. Analysis of upstream activation sites of yeast ribosomal protein genes. Nucleic Acids Res. 15:6037-6047.

51. Woudt, L. P., A. B. Smit, W. H. Mager, and R. J. Planta. 1986. Conserved sequence elements upstream of the gene encoding yeast ribosomal protein $\mathrm{L} 25$ are involved in transcription activation. EMBO J. 5:1037-1040. 